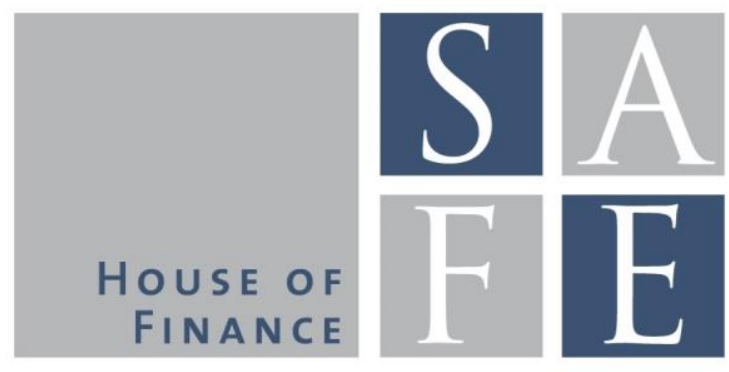

Working PAPER SERIES

Carlo Wix

\title{
The Long-Run Real Effects of Banking Crises: Firm-Level Investment Dynamics and the Role of Wage Rigidity
}

SAFE Working Paper No. 189

SAFE I Sustainable Architecture for Finance in Europe A cooperation of the Center for Financial Studies and Goethe University Frankfurt 


\section{Non-Technical Summary}

Labor costs make up a large share of firms' total costs and therefore firms might be forced to reduce payroll expenses when they face financial constraints due to reduced credit availability. Financially constrained firms can, in principle, reduce their payroll expenses along two different margins: They can either discharge workers while keeping wages fixed, or they can lower wages while avoiding layoffs and keeping employment stable. On the one hand, the notion of wage rigidity suggests that financially constrained firms may find it easier to reduce labor costs by laying off workers rather than by lowering wages. On the other hand, the concept of labor hoarding posits that, if feasible, adjusting wages while retaining workers allows firms to avoid the costs of firing, re-hiring, and re-training workers; thereby putting them in a better position to expand when the economy recovers. Thus, the inability or unwillingness of firms to reduce their payroll by cutting wages is likely to exacerbate the long-run effects of credit market disruptions on real firm outcomes.

In this paper, I study the long-run effects of the 2008-09 financial crisis on corporate investment and firm growth and how these effects depend on nominal wage rigidities at the firm level. Empirically investigating the effect of credit availability on firm behavior faces the challenge of disentangling banks' credit supply from firms' credit demand. To address this challenge, I use loan- and firm-level data of U.S. nonfinancial firms and exploit variation in the refinancing needs of firms during the 2008-09 financial crisis due to maturing term loans and expiring credit lines. Moreover, I construct a firm-level measure of wage rigidity which is based on the decomposition of payroll changes into changes in the average wage and changes in employment. Firms with a higher degree of wage rigidity can be expected to adjust their payroll via changes in the level of employment rather than via changes in the level of the average wage. I then assess how the presence of rigid wages (as measured by the wage share of payroll adjustments) affects the long-run investment policies and recovery growth paths of firms following a credit supply shock.

My main findings are as follows: First, I show that firms which are more adversely affected by the reduced credit availability during the 2008-09 financial crisis exhibit an investment gap of 2 percentage points on a quarterly basis over a period of 2 years compared to similar firms less affected by the reduced credit availability. Two years after the crisis, this investment gap closes and both groups of firms converge to similar investment paths. However, affected firms do not invest more when access to external finance becomes available again and do not offset the temporary investment gap. Hence, this temporary investment gap due to temporarily reduced credit availability results in a persistent accumulated growth gap of 8 percentage points which is still present a full 6 years after the banking crisis. Therefore, I provide novel firm-level evidence of persistent negative long-run effects of banking crises on the real economy. I then show that wage rigidities at the firm level significantly exacerbate these negative long-run effects. I find that firms with more rigid wages respond to reduced credit availability by laying off workers, while firms with flexible wages respond by reducing wages. Latter firms are thus able to keep their workforce on board during the crisis and can therefore avoid the costs of firing, re-hiring, and retraining workers after the crisis. Hence, they are in a better position to expand when the economy recovers. Consistent with this, I find that firms with more rigid wages exhibit a steeper drop in investment and grow more slowly than affected firms with more flexible wages. 
My paper emphasizes the role of labor market frictions in the amplification of financial shocks and has important policy implications. My results suggest that policy measures which enhance wage flexibility and/or facilitate labor hoarding behavior of firms might be suitable to alleviate the negative real effects of banking crises. This is consistent with the so called "German labor market miracle" and the fast recovery of the German economy in the aftermath of the 2008-09 financial crisis. During the crisis, the German government aggressively expanded short-time work ("Kurzarbeit") programs which subsidized the payroll expenses of firms which refrained from laying off workers. These policy measures effectively constituted an injection of wage flexibility into the German labor market and allowed firms to weather the crisis while keeping their workforce on board, putting them in a better position to quickly scale back operations following the crisis. The results in my paper provide corroborating evidence for this economic mechanism. 


\title{
The Long-Run Real Effects of Banking Crises: Firm-Level Investment Dynamics and the Role of Wage Rigidity
}

\author{
CARLO WIX* \\ Goethe University Frankfurt
}

This Version: November 2017

\begin{abstract}
This paper studies the long-run effects of credit market disruptions on real firm outcomes and how these effects depend on nominal wage rigidities at the firm level. I trace out the long-run investment and growth trajectories of firms which are more adversely affected by a transitory shock to aggregate credit supply. Affected firms exhibit a temporary investment gap for two years following the shock, resulting in a persistent accumulated growth gap. I show that affected firms with a higher degree of wage rigidity exhibit a steeper drop in investment and grow more slowly than affected firms with more flexible wages.
\end{abstract}

\footnotetext{
${ }^{*}$ Research Center SAFE at Goethe University Frankfurt. Email: wix@safe.uni-frankfurt.de. I am extremely grateful to my advisor Reint Gropp for his continued encouragement, guidance and support. I thank my discussant Laura García-Jorcano and the conference participants at the $25^{\text {th }}$ Finance Forum (Barcelona). I also appreciate helpful comments from Heitor Almeida, Tobias Berg, Florian Deuflhard, David Dorn, Sebastian Dörr, Satyajit Dutt, Emilia García-Appendini, Martin Götz, Tobin Hanspal, Rainer Haselmann, Christian Hirsch, Jan Pieter Krahnen, Thomas Mosk, Steffen Müller, Steven Ongena, Vahid Saadi, Gregor von Schweinitz, Adjmal Sirak, Javier Suárez, Anjan Thakor, Hans-Joachim Voth, and the seminar participants at Goethe University Frankfurt, the Halle Institute of Economic Research, and the University of Zurich. I gratefully acknowledge financial support from the Research Center SAFE, funded by State of Hessen research initiative LOEWE, and the Halle Institute of Economic Research. I appreciate the hospitality of the Department of Banking and Finance at University of Zurich while writing this paper.
} 
The Global Financial Crisis of 2008-09 was followed by the Great Recession and a subsequent slow recovery both in the United States and many other advanced economies (Reinhart and Rogoff, 2014). The protracted nature of the recovery as well as considerable heterogeneity in the recovery paths across countries has sparked an ongoing debate about the long-run real effects of banking crises, with many important questions remaining unresolved (Romer and Romer, 2017). To what extent does the aftermath of banking crises represent a causal relationship between credit market disruptions and economic activity? Do banking crises have persistent negative real effects or is there a full recovery in the long run? And what explains the heterogeneity in the recovery paths across countries?

Answering these questions empirically is challenging. First, the observed negative correlation between banking crises and real outcomes does not necessarily imply a causal effect of credit market disruptions on economic activity (Dell'Ariccia, Detragiache, and Rajan, 2008). An adverse economic shock could also cause financial distress in the banking sector through a reduction in credit demand, suggesting reverse causality. However, disentangling banks' credit supply from credit demand is difficult, especially when using aggregate data. ${ }^{1}$ Second, assessing the long-run effects of banking crises and the extent of the recovery requires a measure of "returning to normal" (Fatás and Mihov, 2013). The existing literature on the recovery of real GDP following financial crises employs two different measures of recovery: The deviations of GDP from the previous peak (Reinhart and Rogoff, 2014) and the deviations of GDP from potential output, that is the output gap. The first measure has the drawback that it ignores the growth of the trend occurring during recessions, and the second measure has the disadvantage that potential output and the output gap can only be estimated with great uncertainty. Thus, both approaches (again relying on aggregate data) suffer from the lack of a credible counterfactual of how economic activity would have evolved in the absence of a banking crisis. Finally, explaining the heterogeneity in the recovery paths across countries faces the challenge that countries differ vastly along many important economic dimensions. This makes it difficult to isolate specific channels (for example labor market frictions) affecting the recovery trajectories following a banking crisis. How banking crises affect real outcomes in the long run and what explains variation in the aftermath of banking crises thus remain empirical questions.

\footnotetext{
${ }^{1}$ Consistent with the empirical approach in this paper, Romer and Romer (2017) suggest that "the most fruitful approach to establishing causation may lie in combining natural experiments with detailed cross-section evidence."
} 
In this paper, I study the long-run effects of the 2008-09 financial crisis on corporate investment and firm growth and how these effects depend on nominal wage rigidities at the firm level. To address the empirical challenges mentioned above, I use loan- and firm-level data and exploit exogenous variation in the refinancing needs of U.S. firms during the 2008-09 financial crisis to identify the effect of credit market disruptions on real firm outcomes. I use a local projection difference-in-differences matching estimation approach and trace out the trajectories of investment and firm growth over a period of 6 years after the crisis for firms more adversely affected by the reduction in aggregate credit supply. Moreover, I construct a novel firm-level measure of wage rigidity consistent with the notion of labor hoarding and based on the decomposition of payroll changes into changes in the average wage and changes in employment. I assess how the presence of rigid wages at the firm level affects the response of firms to a credit supply shock.

My main findings are as follows. First, I show that firms which are more adversely affected by a reduction in aggregate credit supply reduce investment by 2 percentage points over a period of 2 years compared to similar firms in the control group. These results are consistent with the shortrun findings of the existing corporate finance literature on the effects of credit market disruptions on firm investment. I then investigate how affected firms adjust their investment policies in the long run and provide novel evidence on firms' recovery paths after the initial drop in investment. I find that 2 years after the shock the investment gap closes and both groups of firms converge to similar investment paths. There is, however, no catch-up effect in the long run. Affected firms do not invest more when access to external finance becomes available again and do not offset the temporary investment gap. Hence, this temporary investment gap due to a transitory credit supply shock results in a persistent accumulated growth gap of 8 percentage points which is present a full 6 years after the banking crisis. These findings provide novel firm-level evidence of significant longrun effects of banking crises on real outcomes. Finally, I show that wage rigidities at the firm level significantly exacerbate the negative long-run effects of credit market disruptions. Consistent with the notion of labor hoarding, I find that affected firms with more rigid wages exhibit a steeper drop in investment and grow more slowly than affected firms with more flexible wages. These results emphasize the role of labor market frictions in the amplification of financial shocks and provide corroborating evidence for recent findings in the macroeconomic literature on financial frictions (Ajello, 2016). 
Empirically investigating the effect of credit availability on firm behavior faces the traditional identification challenge of disentangling banks' credit supply from firms' credit demand. Following Peek and Rosengren (2000), a number of papers in the corporate finance literature employ identification strategies based on negative shocks to bank health resulting in reduced bank-specific credit supply to study the effect on firms borrowing from the affected banks. ${ }^{2}$ While such shocks are arguably exogenous with respect to aggregate firm demand, identification relying on bank-firm relationships additionally requires the assumption that bank-firm matching in the loan market is exogenous to firm-specific credit demand, an assumption which has recently been called into question (Schwert, 2017).

In contrast, the empirical strategy employed in this paper does not rely on bank-firm relationships for identification. I exploit exogenous variation in the refinancing needs of U.S. firms due to maturing term loans and expiring credit lines during the credit crunch in the wake of the 2008-09 financial crisis. Since such long-term debt instruments are a large and important source of corporate funding (Sufi, 2007), firms with refinancing needs during this period can be expected to be more adversely affected by the credit crunch than firms which do not have to roll over maturing debt during this same period. ${ }^{3}$

My empirical strategy relies on two identification assumptions. First, the 2008-09 financial crisis arguably constituted a period of reduced credit availability in the aggregate. Ivashina and Scharfstein (2010) show that the observed drop in syndicated lending during this period cannot be explained by demand effects alone. Similarly, Adrian, Colla, and Shin (2013) report that the evidence points overwhelmingly to a shock in the supply of credit by banks. Although Becker and Ivashina (2014) provide evidence that during the financial crisis firms substituted away from contracting bank credit supply toward public debt, Adrian, Colla, and Shin (2013) show that the outward shift of the demand curve for bond financing steeply increased the cost of external financing even for firms with access to the bond market. Furthermore, the financial crisis did

\footnotetext{
${ }^{2}$ In this spirit, Chava and Purnanandam (2011) exploit banks' exposure to Russian sovereign debt during the Russian crisis in 1998; Chodorow-Reich (2014) exploits variation in lender health following the Lehman bankruptcy in 2008; and Acharya, Eisert, Eufinger, and Hirsch (2016) exploit banks' exposure to the European sovereign debt crisis from 2010 to 2012 .

${ }^{3}$ My identification strategy is similar in spirit to that of Almeida, Campello, Laranjeira, and Weisbenner (2012). While their study is based on firm balance sheet data, I additionally make use of loan-level data containing detailed information on the maturity and expiration dates of individual loan facilities. Similar identification ideas have recently also been employed by Duval, Hong, and Timmer (2017) and Garicano and Steinwender (2016).
} 
not only negatively impact the supply of bank credit and the cost of bond finance, but also the commercial paper market (Kacperczyk and Schnabl, 2010) and firms' costs of issuing equity (Belo, Lin, and Yang, 2014). Thus, firms facing the need to substitute maturing term loans or expiring credit lines with other sources of external financing during this period were likely to suffer from the financial frictions affecting all modes of corporate funding.

Second, firms' refinancing needs during the credit crunch in the wake of the 2008-09 financial crisis can plausibly be considered exogenous to firms' performance in the years following the shock. As I will show in Section III, the maturity of the median loan facility in my sample is 5 years. Thus, whether a firm had a term loan maturing or a credit line expiring during this period of reduced credit availability is determined by decisions made several years in the past. It is difficult to argue that a firm which took out a term loan or credit line in 2004 made this decision anticipating the refinancing difficulties it would face 5 years down the road. This exogenous variation in refinancing needs translates into quasi-experimental variation in how adversely a firm is affected by the reduction in aggregate credit supply.

I exploit this exogenous variation in firms' exposure to the credit crunch and employ a differencein-differences matching estimation approach to identify how affected firms adjust their corporate policies and growth trajectories in the long run compared to otherwise similar firms less affected by the reduction in aggregate credit supply. Instead of collapsing my sample into a single pre- and post-treatment period, I separately estimate the treatment effect for the change in firm outcomes between my pre-treatment period and each of the quarters during my post-treatment period. This allows me to disentangle short-run effects from long-run effects and trace out a treatment effect curve over time similar in spirit to the local projection method of estimating impulse response functions.

I then investigate how wage rigidities at the firm level affect the recovery paths of firms following a banking crisis. While wage rigidity is a well-documented feature of the labor market and a central topic in the macroeconomic literature on financial frictions, its firm-level consequences have received relatively little attention thus far. However, payroll expenses make up a large share of firms' total costs (see e.g. Klasa, Maxwell, and Ortiz-Molina (2009)). Thus, the inability or unwillingness of firms to reduce labor costs by lowering wages is likely to affect corporate investment and employment, especially in the case of financially constrained firms. Moreover, the concept of 
labor hoarding posits that, if feasible, adjusting wages while retaining workers allows firms to avoid the costs of firing, re-hiring, and re-training workers; thereby putting them in a better position to expand when the economy recovers (Biddle, 2014). To assess how the presence of rigid wages affects the recovery paths of firms to a credit supply shock, I construct a novel firm-level measure of wage rigidity based on the decomposition of payroll changes into components related to changes in the average wage and changes in employment. I then separately trace out the trajectories of investment, firm growth, employment, and wages for financially constrained firms with high and low levels of wage rigidity.

The remainder of this paper proceeds as follows. Section I discusses how my paper contributes to the related literature. In Section II, I discuss the empirical strategy used for identification. Section III describes the data. Section IV reports the results on the long-run real effects of banking crises and Section $\mathrm{V}$ reports the results on the role of wage rigidity. Robustness checks are presented in Section VI. Section VII concludes.

\section{Literature}

Since the financial crisis of 2008-09, a growing literature in both corporate finance and macroeconomics examines the effects of bank lending frictions on the real economy. Despite sharing common themes and insights, these two strands of literature remain largely disconnected regarding two important aspects: The long-run effects of financial shocks and the role of wage rigidity in amplifying these shocks. While these two aspects are central topics in the macroeconomic literature on financial frictions, they have received little attention in the empirical corporate finance literature thus far. In this paper, I attempt to bridge the gap between these two strands of literature by studying these questions from a corporate finance perspective.

My paper therefore contributes to several strands of literature. First, my work complements and extends the existing corporate finance literature on the short-run effects of credit market disruptions on real firm outcomes. Chava and Purnanandam (2011) find that firms dependent on banks with substantial exposure to Russian sovereign debt in 1998 significantly cut their investment in the 6 quarters after the shock. Almeida, Campello, Laranjeira, and Weisbenner (2012) employ a similar identification strategy as this paper and find that firms with a large fraction of their long-term 
debt maturing during the financial crisis reduce investment by 2.5 percentage points over the next 3 quarters compared to firms in the control group. Studying employment effects, Chodorow-Reich (2014) exploits variation in lender health following the Lehman Brothers bankruptcy and shows that firms borrowing from less healthy lenders experience an additional decline in employment of 4 percentage points. Finally, Cingano, Manaresi, and Sette (2016) use Italian credit register data and find that for firms borrowing from banks affected by the 2007 interbank market freeze, total investment expenditure in the 4 subsequent years would have been more than 20 percent higher than observed. While this literature so far focuses on a short-run horizon of 3 to 8 quarters following a credit supply shock, it provides little evidence on the recovery paths of firms in the aftermath of the shock. In contrast, my paper studies the long-run effects of credit market disruptions over a time horizon of 6 years following the shock. ${ }^{4}$ This allows me to assess both the short-run effects on firms' corporate policies immediately following the shock, as well as the long-run adjustments made by firms in the aftermath of a banking crisis.

My paper also contributes to the macroeconomic literature on recoveries from financial crises. In an early study, Cerra and Saxena (2008) document the behavior of output following financial (and political) crises in 190 countries and find highly persistent output losses ranging between 4 and 16 percent by the end of 10 years following various crises. Papell and Prodan (2012) study the statistical behavior of GDP after financial crises and find, in contrast to Cerra and Saxena (2008), that after on average 9 years output returns to its trend growth path, so that long-run potential GDP is not affected. Fatás and Mihov (2013) provide a discussion of the difficulties associated with "measuring recovery" when using aggregate data. They analyze the recoveries for the U.S. business cycles since 1950 and find considerable heterogeneity in the speed and shape of recovery phases associated with different recession periods. In a comprehensive study, Reinhart and Rogoff (2014) examine the evolution of real per capita GDP around 100 banking crises. They measure the duration of recovery as the number of years it takes to reach the prior peak in real per capita GDP and find that recoveries from financial crises take on average 8 years. ${ }^{5}$ Most recently, Romer and

\footnotetext{
${ }^{4}$ Cingano, Manaresi, and Sette (2016) also consider a longer time horizon of 4 years. However, their analysis is restricted to a period of reduced credit supply during the first phase of the Italian recession (2006-2010). As credit supply in the Italian banking sector is considered to be still significantly below pre-crisis levels IMF (2016), their paper investigates the effect of a prolonged reduction in credit supply on firms' corporate policies, but does not study the recovery paths of firms in the long run when credit becomes available again.

${ }^{5}$ See Reinhart and Rogoff (2009a) and Reinhart and Rogoff (2009b) for related studies.
} 
Romer (2017) provide new evidence on the aftermath of financial crises in advanced countries using a new measure of financial distress derived from narrative accounts in the OECD Economic Outlooks. They find that the average decline in output following a financial crisis is statistically significant, but only moderate in size with about 6 percent. Moreover, they report large heterogeneity in the aftermaths of financial crises across different countries, highlighting the need for further research on what accounts for this large variation. While this literature suggests a causal effect of banking crises on long-run real outcomes, most papers acknowledge that this evidence is far from conclusive. As identifying exogenous shocks to credit supply is difficult when using aggregate data, Romer and Romer (2017) suggest that "the most fruitful approach to establishing causation may lie in combining natural experiments with detailed cross-section evidence." My paper contributes to this literature by providing such quasi-experimental micro-level evidence.

More generally, my paper also contributes to the macroeconomic literature on financial frictions by providing novel firm-level evidence on the long-run effects of financial shocks and the role of wage rigidity in the propagation and amplification of such shocks. ${ }^{6}$ Following Bernanke, Gertler, and Gilchrist (1999), earlier papers in the financial frictions literature study the role of credit markets as a "financial accelerator" for the amplification of shocks originating in other sectors of the economy. In contrast, more recent papers investigate shocks originating in the financial sector. Jermann and Quadrini (2012) model financial shocks as innovations to the borrowing capacity of firms and find that such shocks are important for capturing the dynamics of real business cycle quantities, especially the demand for labor. Christiano, Motto, and Rostagno (2014) investigate shocks to the riskiness of credit contracts and report that such "risk shocks" account for a large share of the fluctuations in investment and other macroeconomic variables. Closest in spirit to this paper, Ajello (2016) reports that shocks to the cost of financial intermediation account for thirty percent of the fluctuations in investment and that wage rigidities are a necessary feature to create amplification of financial shocks. My paper is complementary to this literature regarding two aspects: First, while identification in macroeconomics is often based on the calibration of structural models, I exploit quasi-experimental variation in firms' refinancing needs for identification. Second, whereas the macroeconomic literature focuses on the dynamics of aggregate variables, I study these

\footnotetext{
${ }^{6}$ See Brunnermeier, Eisenbach, and Sannikov (2012) for a comprehensive survey of the macroeconomic literature on financial frictions.
} 
questions from a corporate finance perspective and provide firm-level evidence on the long-run effects of financial shocks and the role of wage rigidity.

Finally, my paper is also related to a growing stream of literature on the interaction of financial and labor market frictions. Schoefer (2015) explores the financial channel of wage rigidity and inter alia concludes that smoother cash flows from less rigid wages would help firms whether recessions with smoother investment and employment. Ouimet and Simintzi (2017) exploit heterogeneity in the timing of long-term wage agreements of UK firms to examine the effect of higher wages on firm performance during the 2008 financial crisis. Wang (2017) calibrates an equilibrium model of wage dynamics and finds that more flexible wage profiles can help mitigate the effects of financial constraints on investment. I contribute to this growing literature by exploiting a quasi-experimental shock to credit supply and explicitly investigating how wage rigidity affects the short- and long-run response of firms to such a shock.

\section{Empirical Strategy}

My empirical strategy relies on two important identification assumptions: First, the 2008-09 financial crisis arguably constituted a shock to aggregate credit supply. Second, the extent to which a firm was affected by this reduction in aggregate credit supply can plausibly be considered exogenous to the firm's performance in the years following the shock. In this section, I first discuss the two identification assumptions. I then describe the local projection difference-in-differences matching estimator and finally explain how I use my proposed firm-level measure of wage rigidity to investigate the role of wage rigidity in the amplification of credit supply shocks.

\section{A. $\quad$ The 2009 Credit Crunch in the Syndicated Loan Market}

The 2008-09 financial crisis constituted a period of limited access to many sources of external financing. In this paper, I focus on the credit crunch in the syndicated loan market using loan-level data from Thomson Reuters LPC's Dealscan database. Syndicated loans, that is term loans and

credit lines, are a large and important source of corporate finance (Sufi, 2007). Figure 1 shows the detrended quarterly total log volume of newly issued term loans and credit lines to U.S. nonfinancial borrowers over the period from 1995 to 2016. The two dashed horizontal lines denote two standard 
deviations around the mean volume of newly issued loans over the whole period. As indicated by the two dashed vertical lines, between the fourth quarter of 2008 and the first quarter of 2010 credit activity in the syndicated loan market fell significantly below the long-run average of loan originations.

[Figure 1 about here]

In principle, this observed drop in credit activity might not reflect a credit crunch but could be driven by a reduction in firms' credit demand. However, Ivashina and Scharfstein (2010) show that the reduction in syndicated lending in the wake of the financial crisis cannot be explained by demand effects alone. Likewise, Adrian, Colla, and Shin (2013) argue that the evidence from the 2008-09 financial crisis points overwhelmingly to a shock in the supply of credit by banks and other financial intermediaries. ${ }^{7}$ It is, however, possible that during the crisis firms substituted away from contracting bank credit supply toward other sources of external finance to mitigate the negative effects of the credit crunch. While Becker and Ivashina (2014) provide evidence for firms' substitution away from contracting bank credit supply toward public debt, Adrian, Colla, and Shin (2013) show that the outward shift of the demand curve for bond financing steeply increased the cost of external financing even for firms with access to the bond market (see also Friewald, Jankowitsch, and Subrahmanyam (2012)). Furthermore, the 2008-09 financial crisis also negatively affected the commercial paper market (Kacperczyk and Schnabl, 2010) and firms' costs of issuing equity (Belo, Lin, and Yang, 2014). Thus, firms facing the need to substitute maturing term loans or expiring credit lines with other sources of external financing during this period were likely to suffer from the financial frictions affecting all modes of corporate funding. It should also be noted that my identification strategy does not depend on the contraction in syndicated lending to be purely supply-side driven. I only require that there was (besides possible demand effects) a significant and sizable drop in the supply of credit which made it harder and costlier for firms to substitute maturing loans with new credit in the syndicated loan market or other sources of external finance. Thus, I argue that the period from 2008-Q4 to 2010-Q1 constituted a period of reduced

\footnotetext{
${ }^{7}$ In a similar vein, Almeida, Campello, Laranjeira, and Weisbenner (2012), Becker and Ivashina (2014), Campello, Graham, and Harvey (2010), and Chodorow-Reich (2014) also argue that the observed reduction in lending activity during the crisis can (mainly) be attributed to a reduction in credit supply rather than (purely) be attributed to a reduction in credit demand.
} 
access to external financing which defines the treatment period in this paper. Section VI provides a robustness check using an alternative definition of the credit crunch period in the syndicated loan market.

\section{B. Exogenous Variation in Firms' Refinancing Needs}

The extent to which a firm is affected by this reduction in aggregate credit supply depends on the firm's need for external financing. Financing needs are particularly high for firms which are confronted with the necessity to refinance maturing term loans or substitute expiring credit lines. The Thomson Reuters LPC's Dealscan database contains data on syndicated loans at the individual loan facility level, including information on the maturity and end date of each facility. With reference to the refinancing risk associated with maturing term loans and expiring credit lines, I define the treatment group to be firms $i$ which had at least one loan facility $j$ maturing during the period from 2008-Q4 to 2010-Q1. Conversely, I define the control group pool to be firms which had neither a term loan maturing nor a credit line expiring during this period.

$$
\text { Treatment }_{i}=\left\{\begin{array}{ccc}
1 & \text { if } \quad \exists \text { Facility }_{i, j}: \text { Maturity Date }\left(\text { Facility }_{i, j}\right) \in[2008-\mathrm{Q} 4,2010-\mathrm{Q} 1] \\
0 & \text { if } \quad{\nexists \text { Facility }_{i, j}}: \text { Maturity Date }\left(\text { Facility }_{i, j}\right) \in[2008-\mathrm{Q} 4,2010-\mathrm{Q} 1]
\end{array}\right.
$$

Note that this definition of treatment firms is rather conservative as the treatment group may contain firms for which the volume of maturing loans constitutes only a small share of the firm's overall corporate financing. Section VI provides a robustness check showing that the results become even stronger, once I only include firms in the treatment group for which the share of maturing loans of overall financing is above a certain threshold. Figure 2 illustrates the basic idea behind my identification strategy.

[Figure 2 about here]

Exploiting firms' refinancing needs for identification requires those needs to be exogenous to firms' performance in the years following the shock. As I show in Section III, the maturity of the median loan facility in my sample is 5 years. Thus, whether a firm had a term loan maturing or credit line expiring during the 2009 credit crunch is determined by financing decisions made several years in the past. It is hard to argue that a firm which took out a loan in 2004 made this decision anticipating 
the refinancing difficulties it would face 5 years down the road. Nonetheless, to alleviate concerns that the results are driven by other firm characteristics potentially correlated with firms' refinancing needs, I combine my difference-in-differences approach with an appropriate matching methodology, as discussed below.

Despite the contraction in credit supply in the wake of the financial crisis, it is still possible that firms with refinancing needs during this period were able to roll over maturing term loans or renew expiring credit lines, which would constitute a threat to my identification strategy. Figure 3 shows the average quarterly outstanding loan volumes for firms in the treatment group and firms in the control group pool relative to the third quarter of 2008.

[Figure 3 about here]

The decrease in outstanding loan volumes for firms in the treatment group starting in the fourth quarter of 2008 indicates those firms were not able to fully refinance their maturing term loans and expiring credit lines.

\section{The Local Projection Difference-in-Differences Matching Estimation Approach}

The quasi-experimental variation in how adversely firms were affected by the contraction in credit supply lends itself to a difference-in-differences research design. To alleviate concerns that my results are driven by other firm characteristics which were found to be associated with refinancing risk or firms' corporate policies, I combine the difference-in-differences approach with an appropriate matching methodology. This paper uses the bias-corrected Abadie and Imbens (2006) matching estimator, which has recently been used in the corporate finance literature by Almeida, Campello, Laranjeira, and Weisbenner (2012), Campello and Giambona (2013), Gropp, Mosk, Ongena, and Wix (2016), and Kahle and Stulz (2013). ${ }^{8}$ In contrast to standard propensity score matching, the Abadie and Imbens (2006) matching estimator minimizes the (Mahalanobis) distance between a vector of observed matching covariates across firms in the treatment group and firms in the control group pool and introduces a bias correction to account for inexact matches on continuous variables. The estimator conveniently allows for exact matches on predefined categorical matching covariates (e.g. the SIC industry code) and additionally produces heteroskedastic-robust standard errors.

\footnotetext{
${ }^{8}$ See Abadie and Imbens (2002) and Abadie and Imbens (2006) for a more detailed explanation and Abadie, Drukker, Herr, and Imbens (2004) for an implementation of this estimator.
} 
To each firm in my treatment group, I match one firm from the pool of control group firms to produce a balanced sample in terms of firm size, the investment ratio, cash holdings, Q, cash flow, return on assets, and long-term leverage as of 2008-Q3, the quarter immediately before the treatment period. These matching covariates capture potential differences in firms' growth prospects, liquidity, profitability, and capital structure prior to the financial crisis. Additionally, I require an exact match on the 1-digit SIC industry code. The main outcome variables examined are the change in investment, the change in the logarithm of property, plant, and equipment (PPE) assets as a measure of firm growth, the change in the logarithm of employment, and the change in the logarithm of wages.

I estimate the average treatment effect on the treated (ATT) for the change in the outcome variables between 2008-Q3 (the quarter immediately before the treatment period) and each of the 23 post-treatment quarters from 2010-Q2 to 2015-Q4. Thus, I estimate

$$
\widehat{\tau}_{A T T}^{h}=\frac{1}{N_{T}} \sum_{i: T_{i}=1}\left[\Delta^{h} Y_{i}-\Delta^{h} \tilde{Y}_{i}(0)\right] \quad \forall h=1, \cdots, 23
$$

where $N_{T}$ is the number of firms in the treatment group, $T_{i}=1$ denotes the belonging of firm $i$ to the treatment group, $\Delta^{h} Y_{i}$ is the observed change in outcome variable $Y$ between the pre-treatment period and the $h^{t h}$ quarter of the post-treatment period for treatment firm $i$, and $\Delta^{h} \tilde{Y}_{i}(0)$ the corresponding imputed value of the change in the outcome variable for the matched control firm.

Separately estimating the treatment effect for each of the post-treatment quarters, instead of collapsing my sample into a single pre- and post-treatment period, allows me to disentangle shortrun effects from long-run effects and trace out a treatment effect curve over time. This methodology is similar in spirit to the local projection method of estimating impulse response functions (Jordà, 2005), which is based on sequential regressions of the endogenous variable shifted forward in time. ${ }^{9}$

\section{Measuring Firm-Level Wage Rigidity: The Wage Share of Payroll Adjustment}

Besides providing little evidence on the long-run effects of credit market disruptions, the existing corporate finance literature also has little to say about how wage rigidity affects the response of

\footnotetext{
${ }^{9}$ See Favara and Imbs (2015), Jordà, Schularick, and Taylor (2013), Jordà, Richter, Schularick, and Taylor (2017), and Mian, Sufi, and Verner (2017) for recent applications of local projection techniques in Finance.
} 
firms to financial shocks. However, downward nominal wage rigidity (the scarcity of nominal wages cuts even during recessions) is a well-documented feature of the labor market. ${ }^{10}$ The notion of wage rigidity suggests that financially constrained firms may find it easier to reduce labor costs by laying off workers rather than by lowering wages (see e.g. Pischke (2016)). On the other hand, the concept of labor hoarding posits that, if feasible, adjusting wages while retaining workers allows firms to avoid the costs of firing, re-hiring, and re-training workers; thereby putting them in a better position to expand when the economy recovers (Biddle, 2014). Thus, as payroll expenses make up a large share of firms' total costs (see e.g. Klasa, Maxwell, and Ortiz-Molina (2009)), the inability or unwillingness of firms to reduce their payroll by cutting wages is likely to exacerbate the long-run effects of credit market disruptions on real firm outcomes.

In this paper, I construct a novel firm-level measure of wage rigidity to assess how the presence of rigid wages affects the response of firms to a credit supply shock. My proposed measure is based on premise that firms can essentially reduce their payroll expenses along two different margins: They can either discharge workers while keeping wages fixed, or they can lower wages while avoiding layoffs and keeping employment stable. ${ }^{11}$ Pischke (2016) shows that employment fluctuations are stronger for occupations with more rigid wages than for occupations with more flexible wages. Thus, firms with a higher degree of wage rigidity can be expected to adjust their payroll via changes in the level of employment rather than via changes in the level of the average wage. Since the payroll of a firm $i$ in quarter $t$ is given by the product of its number of employees and its average wage paid, this implies

$$
\Delta \log \left(\text { Payroll }_{i, t}\right)=\Delta \log \left(\text { Employment }_{i, t}\right)+\Delta \log \left(\overline{\text { Wage }_{i, t}}\right)
$$

I define my measure of wage rigidity for firm $i$ as the wage share of payroll adjustment $\theta_{i}$ given by

$$
\theta_{i}=\frac{1}{T} \sum_{t=1}^{T} \frac{\Delta \log \left(\overline{\text { Wage }_{i, t}}\right)}{\Delta \log \left(\text { Payroll }_{i, t}\right)}
$$

where $T$ is the number of quarters in the pre-treatment period over which the measure is calculated.

\footnotetext{
${ }^{10}$ See Dickens et al. (2007) for a comprehensive study on downward nominal wage rigidity in 16 countries.

${ }^{11}$ Due to data constraints, I abstract from other margins of labor cost adjustment, such as bonuses and non-pay benefits.
} 
According to this notion of wage rigidity based on Pischke (2016), I define firms with low values of $\theta$ to have a high degree of wage rigidity and firms with high values of $\theta$ to have a low degree of wage rigidity. To assess how the presence of rigid wages affects the response of firms to a credit supply shock, I split the treatment group of affected firms by the median value of $\theta$ into two subsamples: Affected firms with a high degree of wage rigidity and affected firms with a low degrees of wage rigidity;

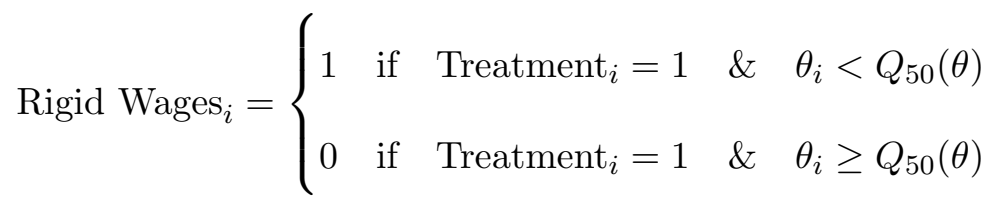

where Treatment ${ }_{i}$ is the treatment variable as defined in Equation 1 in Section II.B, $\theta_{i}$ is the firmlevel measure of wage rigidity as defined in Equation 4 , and $Q_{50}(\theta)$ is the median value of $\theta$ for firms in the treatment group.

I then conduct two different matching exercises. First, to compare the treatment effect curves for the full sample with those for the two subsamples, I run the matching estimation described in Section II.C separately for financially constrained with rigid wages

$$
T_{i}^{\text {Rigid }}=\left\{\begin{array}{llll}
1 & \text { if } & \text { Treatment }_{i}=1 \quad \& \quad \text { Rigid }_{\text {Wages }}=1 \\
0 & \text { if } & \text { Treatment }_{i}=0
\end{array}\right.
$$

and financially constrained firms with flexible wages

$$
T_{i}^{\text {Flexible }}=\left\{\begin{array}{lll}
1 \quad \text { if } & \text { Treatment }_{i}=1 \quad \& \quad \text { Rigid }_{\text {Wages }}=0 \\
0 & \text { if } & \text { Treatment }_{i}=0
\end{array}\right.
$$

and trace out the treatment effect curves on investment, growth, employment, and wages for each of the two groups.

This analysis, however, is subject to the caveat that wage rigidities at the firm level could be correlated with other firm characteristics which might explain the heterogeneity in firms' responses to a credit supply shock. The main concern in this regard is firm size. Previous literature has found 
that small firms tend to exhibit a higher degree of wage rigidity than large firms. ${ }^{12}$ Large firms, however, are also likely to be less affected by a reduction in bank credit supply, as they tend to have better access to alternative sources of external finance in both bond and equity markets. To alleviate these concerns, I conduct a within treatment group matching exercise. I match affected firms with rigid wages to affected firms with flexible wages to produce a sample of treatment group firms which is balanced in terms of relevant firm characteristics:

$$
T_{i}^{\text {Rigid vs. Flexible }}=\left\{\begin{array}{ccccc}
1 & \text { if } & \text { Treatment }_{i}=1 & \& & \text { Rigid }^{\text {Wages }} \\
& & & & \\
0 & \text { if } & \text { Treatment }_{i}=1 & \& & \text { Rigid }_{\text {Wages }_{i}}=0
\end{array}\right.
$$

I then run the matching estimation described in Section II.C for this sample and trace out the treatment effect curves on investment, growth, employment, and wages for affected firms with a high degree of wage rigidity.

\section{Data}

I construct a novel data set combining data from three different sources. I obtain loan-level data on syndicated loans from Thomson Reuters LPC's Dealscan database, quarterly data on firms' balance sheets and income statements from Compustat's North America Fundamentals Quarterly database, and data on wages from the Quarterly Workforce Indicators (QWI) data set of the Longitudinal Employer-Household Dynamics (LEHD) program of the U.S. Census Bureau. The definitions of all variables used in the paper are summarized in Table I.

[Table I about here]

\section{A. Loan-Level Data}

The Thomson Reuter LPC's database contains detailed loan-level information on syndicated loan contract terms, maturities, as well as the identities of borrowers and lenders. I begin by collecting all term loan and credit line facilities issued by U.S. firms over the period from 1985

\footnotetext{
${ }^{12} \mathrm{Du}$ Caju, Fuss, and Wintr (2007) find that wage rigidity is much higher for small firms, as large firms usually have firm-level collective wage agreements which enhances wage flexibility. Similarly, Avouyi-Dovi, Fougére, and Gautier (2013) report that negotiating wages is more costly for small firms, resulting in a lower frequency of wage changes.
} 
to $2016 .{ }^{13}$ I distinguish between loan facilities maturing during the credit crunch period in the syndicated loan market between 2008-Q4 and 2010-Q1 (treatment facilities), and facilities maturing either before 2008-Q4 or after 2010-Q1 (non-treatment facilities). As shown in Table II, syndicated loan facilities tend to be long-term financing instruments. The maturity of the median loan facility in my sample is 60 months, that is 5 years. Thus, whether a firm had a term loan maturing or a credit line expiring during the credit crunch period from 2008-Q4 to 2010-Q1 is determined by financing decisions made several years in the past.

[Table II about here]

The unit of observation in the Dealscan database is a loan facility at the time of origination. To merge loan-level data from Dealscan with quarterly balance sheet data from Compustat, I calculate the outstanding amount of term loans and credit lines of firm $j$ in quarter $t$ using the maturity date contained in the database. The resulting dataset contains the volume of outstanding and maturing loan facilities at the firm-quarter level.

\section{B. Firm Balance Sheet Data}

I then merge this dataset with the Compustat North America Fundamentals Quarterly database using the Dealscan-Compustat Linking Database from Chava and Roberts (2008). ${ }^{14}$ I exclude all financial borrowers (SIC industry codes 6000 - 6999), all not-for-profit and governmental enterprises (SIC codes > 8000), and all firms not incorporated in the U.S. according to Compustat's foreign incorporation code.

The first dependent variable from Compustat is the change in investment, defined as the 4quarter moving average of the ratio of quarterly capital expenditures to the fourth lag of quarterly property, plant, and equipment (PPE) assets. ${ }^{15}$ The second dependent variable from Compustat is the change in the logarithm of PPE assets as a measure of firm growth, and the third dependent variable from Compustat is the change in the logarithm of employment. I conduct my matching procedure to balance treatment and control firms in terms of pre-treatment values of size, investment

\footnotetext{
${ }^{13}$ For term loans and credit lines, I follow the definition of Berg, Saunders, and Steffen (2016).

${ }^{14}$ I thank Sudheer Chava and Michael Roberts for making this Linking Database available on WRDS.

${ }^{15}$ Note that the Compustat item capxy represents year-to-date capital expenditures, which I first transform to reflect quarterly values. I then use the moving average of quarterly values to account for seasonality in capital expenditures.
} 
ratio, cash holdings, Q, cash flow, return on assets, and long-term leverage. Additionally, I require an exact match on the 1-digit SIC industry code. All dependent growth variables are winsorized at the $5 \%$ level to reduce noise from extreme values, and all matching covariates are winsorized at the $1 \%$ level.

\section{Wage and Payroll Data}

I obtain wage data at the State $\times$ 4-digit NAICS industry $\times$ Firm-size level from the Quarterly Workforce Indicators (QWI) dataset of the Longitudinal Employer-Household Dynamics (LEHD) program of the U.S. Census Bureau. ${ }^{16}$ The QWI dataset is based on unemployment insurance (UI) wage records and covers about 92 percent of all private non-farm employment in the U.S. ${ }^{17}$ I obtain quarterly wage data on the average monthly earnings of employees with a stable job throughout the quarter. Following Kuehn, Simutin, and Wang (2017) and Tuzel and Zhang (2017), I merge the QWI data to firms in Compustat based on their 4-digit NAICS industry code, the state of their headquarters, and the number of employees. I calculate a firm's payroll by multiplying the average wage obtained from the QWI dataset with the firm's number of employees obtained from Compustat.

$$
\text { Payroll }_{i, t}=\text { Wage }_{i, t}^{\mathrm{QWI}} \times \text { Employment }_{i, t}^{\mathrm{CS}}
$$

One caveat to this analysis is that the QWI data contains information at the business establishment level. Thus, wage data will be subject to measurement error for firms with production facilities outside of their headquarters state. However, Chaney, Sraer, and Thesmar (2012) show that headquarters and production facilities tend to cluster in the same state, making headquarters location a reasonable proxy for firm location (see also Tuzel and Zhang (2017)). While Compustat contains data on firms' staff expenses, this data item $(X L R)$ is however sparsely populated. To assess the validity of my combined QWI-Compustat payroll measure, I regress this variable against staff

\footnotetext{
${ }^{16}$ The QWI database classifies firms into five size buckets based on the number of employees: 0-19, 20-49, 50-249, 250-499, and 500+ employees.

${ }^{17}$ See Abowd, Stephens, Vilhuber, Andersson, McKinney, Roemer, and Woodcock (2009) for a detailed description of the construction of the Quarterly Workforce Indicators.
} 
expenses from Compustat for firms for which both data sources are available:

$$
\log \left(\operatorname{Payroll}_{i, t}\right)=\alpha+\beta \times \log \left(\mathrm{XLR}_{i, t}\right)+\epsilon_{i, t}
$$

This regression yields a slope coefficient of 0.93 and an adjusted $R^{2}$ of 0.88 . The scatter plot in Figure 4 als shows a strong positive correlation between the two variables. I thus argue that my combined QWI-Compustat payroll measure provides a reasonable approximation for firms' actual payroll expenses. Finally, I use the wage and payroll data from QWI and Compustat to calculate my measure of wage rigidity for each firm as defined in Equation 4 in Section II.

\section{The Long-Run Real Effects of Banking Crises}

\section{A. Matching Quality}

I start the empirical analysis by providing summary statistics of the sample firms before and after matching. Table III shows the mean values of the matching covariates for treated firms, nontreated firms and firms in the matched control group as of 2008-Q3, the quarter immediately before the treatment period. I provide two different matching quality diagnostics for the balancedness of the sample: the standardized bias defined as the difference of sample means between treated and non-treated firms as a percentage of the square root of the average of sample variances in both groups; and the two-sample t-statistic for differences in means.

[Table III about here]

Panel A of Table III compares the 736 treated and 1,013 non-treated firms in the unmatched sample. Treated firms differ from non-treated firms along several important dimensions. The average treated firm is significantly larger than the average non-treated firm, has a lower pre-crisis investment ratio, lower cash holdings, a lower Q, a higher return on assets, and a higher long-term leverage. These differences between treated and non-treated firms emphasize the necessity of employing a matching procedure.

To each of the 736 treated firms in my sample I match one firm from the control group pool of 1,013 non-treated firms to produce a balanced sample in terms of the pre-treatment firm characteristics. Additionally, I require an exact match on the 1-digit SIC industry code. Panel B of Table III 
shows the mean values of the matching covariates for treated firms and matched control firms after applying the matching procedure. The matched sample is balanced in terms of all matching covariates. The standardized bias ranges between 1.54 and 7.78 percent in absolute values and the differences in means become statistically insignificant. This successful matching procedure alleviates concerns that my results might be driven by differences in firms' growth prospects, liquidity, profitability, and capital structure prior to the financial crises.

\section{B. Firm-Level Investment and Growth Dynamics}

I now examine how firms more adversely affected by the reduction in aggregate credit supply adjust their investment policies and growth trajectories over a period of 6 years following the credit supply shock. Identification in a difference-in-differences framework crucially relies on the parallel trend assumption to hold. Figure 5 shows the evolution of the mean change in investment ratios relative to 2008-Q3 for both treated firms (solid blue line) and the sample of matched control firms (dashed red line). The two vertical lines mark 2008-Q4 and 2010-Q1, the beginning and end of the credit crunch period in my sample. The figure shows that, prior to the financial crisis, there is no significant difference in the investment dynamics between the two groups of firms, as indicated by the overlapping $95 \%$ confidence intervals (marked by the dotted lines). Starting in 2008, there is a decrease in investment of similar magnitude for both treated and control firms. After bottoming out in the first quarter of 2010, however, control firms begin to increase their investment at a steeper rate than firms more adversely affected by the reduction in aggregate credit supply. The figure shows a significant gap in investment between treated and control firms up until the first quarter of 2012, when the investment trajectories of the two groups start to converge again.

[Figure 5 about here]

Figure 6 shows the evolution of the mean change in the logarithm of property, plant, and equipment (PPE) assets relative to 2008-Q3 for the two groups of firms. Similarly, there is no significant difference in growth dynamics between the two groups in the period prior to the financial crisis. Starting at the end of the treatment period, and consistent with the investment gap shown in Figure 5, firms more adversely affected by the reduction in aggregate credit supply enter a lower growth trajectory following the credit crunch. Then, after the investment gap closes in 2013, 
treatment and control firms converge to parallel growth paths until the end of the sample period. However, as treated firms do not offset the gap in investment by investing more when credit becomes available again, Figure 6 shows that there remains a persistent growth gap a full 6 years after the credit supply shock. Taken together, Figure 5 and Figure 6 illustrate that my matching procedure does a good job at balancing treated and non-treated firms regarding their pre-treatment trends in investment and firm growth.

[Figure 6 about here]

Columns 1 and 2 of Table IV report the matching estimation results for the average treatment effect on the treated (ATT) on the change in investment. Starting in the third quarter of 2010, firms more adversely affected by the reduction in aggregate credit supply begin to significantly reduce investment by 1.5 percentage points relative to firms in the matched control group. Over the next two years, the investment gap ranges between 1.5 and 1.7 percentage points per quarter. These coefficients are of similar magnitude as those found in previous studies on the short-run effects of credit market disruptions on investment. Almeida et al. (2012) report that firms whose long-term debt was largely maturing at the onset of the financial crisis cut their investment ratio by 2.5 percentage points more on a quarterly basis. Acharya, Eisert, Eufinger, and Hirsch (2016) find that firms borrowing from banks more affected by the European sovereign debt crisis exhibit a decrease in capital expenditures of 6 percentage points in total over a period of 8 quarters. Moreover, my results provide novel evidence on the recovery path of firm investment once credit becomes available again. Beginning in the second quarter of 2012, two years after the end of the credit crunch, the investment gap starts to close and becomes statistically insignificant and close to zero in magnitude. However, there is no catch-up effect in the sense that treated firms do not offset the investment gap from 2010-Q3 to 2012-Q1 and do not invest more than firms in the control group in the following years. Therefore, as reported in columns 3 and 4 of Table IV, this temporary investment gap translates into a significant and persistent growth gap. Firms more adversely affected by the reduction in aggregate credit supply grow 8.6 percentage points less from 2008-Q3 to 2013-Q1 than firms in the control group. This 9 percentage point growth gap does not close and remains statistically significant until the end of the sample period in 2015-Q4.

[Table IV about here] 
Figure 7 and Figure 8 plot the estimated treatment effects on investment and firm growth and trace out treatment effect curves over time resembling impulse response functions used in macroeconomics. The solid lines represent the matching estimates for the ATT based on the results in columns 1 and 3 of Table IV, and the dashed lines represent the corresponding 95\% confidence intervals. The two vertical lines mark 2008-Q4 and 2010-Q1, the beginning and end of the credit crunch period in my sample. The two figures additionally plot the estimated effects for the pretreatment period from 2006-Q1 to 2010-Q1 not reported in Table IV, providing a formal test of the parallel trends assumption. Figure 7 illustrates the temporary drop in investment for treated firms over a period of two years following the credit supply shock. Once credit becomes available again, treated firms converge back to similar levels of investment as control firms, however without offsetting the temporary investment gap. Figure 8 thus illustrates how this temporary gap in investment translates into a persistent growth gap until the end of the sample period. These results provide evidence of significant long-run effects of credit market disruptions on firm growth.

[Figure 7 and Figure 8 about here]

\section{Firm-Level Employment and Wage Dynamics}

I now investigate the effects of the credit supply shock on firm-level employment and wage dynamics. Figure 9 and Figure 10 shows the evolution of employment and wage growth respectively relative to 2008-Q3 for both treated firms (solid blue line) and the sample of matched control firms (dashed red line). The figures illustrate the parallel growth paths for employment and wages prior to the financial crisis. Figure 9 shows a small employment gap between treated and control firms following the financial crisis. On the other hand, Figure 10 shows almost no differences in the post-crisis wage dynamics between the two groups of firms and illustrates the only small overall downward adjustment of wages during the financial crisis. This pattern is in line with the

considerable evidence of downward wage rigidity in the U.S. during and after the Great Recession (Daly, Hobijn, and Lucking, 2012).

[Figure 9 and Figure 10 about here]

Columns 1 and 2 of Table IV report the matching estimation results for the average treatment effect on the treated (ATT) on employment growth. Firms more adversely affected by the reduction in 
aggregate credit supply exhibit an additional decline in employment growth of up to 2.2 percentage points between 2011-Q4 and 2013-Q4. Although these employment effects are not statistically significant, their magnitude is comparable to those found in previous studies. Cingano, Manaresi, and Sette (2016) find that firms affected by a credit crunch lower employment growth by 1.8 percentage points, and Bentolila, Jansen, Jiménez, and Ruano (2015) report employment losses of about 2.2 percentage points due to a credit supply shock. Using confidential data at the establishment level, Chodorow-Reich (2014) reports a somewhat larger effect of 4 percentage points.

Columns 3 and 4 of Table IV report the matching estimation results for the average treatment effect on the treated (ATT) on wage growth. I find small and statistically insignificant wage effects ranging between 0.1 and 1.2 percentage points in the 3 years after the credit crunch. These results are in line with the empirical evidence of a significant amount of downward nominal wage rigidity in the U.S. (Fallick, Lettau, and Wascher, 2016).

[Table $\mathrm{V}$ about here]

Figure 11 and Figure 12 plot the estimated treatment effects on employment and wage growth and trace out the treatment effect curves over time. The solid lines represent the matching estimates for the ATT based on the results in columns 1 and 3 of Table V, and the dashed lines represent the corresponding $95 \%$ confidence intervals. The two vertical lines mark 2008-Q4 and 2010-Q1, the beginning and end of the credit crunch period in my sample. The two figures additionally plot the estimated effects for the pre-treatment period from 2006-Q1 to 2010-Q1 not reported in Table V, providing a formal test of the parallel trends assumption. While the parallel trend assumption holds for the wage dynamics shown in Figure 12, Figure 11 shows that treated and control firms do not share parallel trends in terms of employment growth. Figure 11 illustrates the negative albeit not statistically significant employment gap starting at the end of the credit crunch period, and Figure 12 illustrates the weak response of firms' wage policies in the years after the credit crunch.

[Figure 11 and Figure 12 about here] 


\section{The Role of Wage Rigidity}

I now turn to the question how wage rigidities at the firm level affect firms' investment, growth, employment, and wage dynamics in response to a credit supply shock. While downward nominal wage rigidity is a well-documented feature of the labor market and a central topic in the macroeconomic literature on financial frictions, its consequences have received relatively little attention in the corporate finance literature thus far. In the presence of rigid wages, financially constrained firms may find it easier to reduce labor costs by laying off workers rather than by lowering wages (Pischke, 2016). On the other hand, the concept of labor hoarding posits that, if feasible, adjusting wages while retaining workers allows firms to avoid the costs of firing, re-hiring, and re-training workers; thereby putting them in a better position to expand when the economy recovers. Thus, the inability of unwillingness of firms to reduce their payroll expenses by cutting wages is likely to exacerbate the negative long-run effects of credit market disruptions on real firm outcomes.

To assess how the presence of rigid wages affects the response of firms to a credit supply shock, I split my treatment group of firms more adversely affected by a reduction in aggregate credit supply into two subsamples based on my firm-level measure of wage rigidity: Affected firms with a high degree of wage rigidity and affected firms with a low degree of wage rigidity. I then conduct two different matching exercises. First, to compare the treatment effect curves for the full sample with those for the two subsamples, I run the matching estimation described in Section II separately for affected firms with rigid wages and affected firms with flexible wages and trace out the treatment effect curves for each of the two groups. Second, to alleviate concerns that these results reflect other differences between firms which are correlated with wage rigidity (most importantly firm size), I conduct a within treatment group analysis and match affected firms with rigid wages to affected firms with flexible wages.

\section{A. Affected Firms with Rigid and Flexible Wages versus Unaffected Firms}

This section presents the estimation results of the first matching exercise. I compare the treatment effect curves for the full sample estimated in Section IV with the treatment effect curves for affected firms with rigid wages and affected firms with flexible wages respectively.

Column 1 of Table VI reports the matching estimation results for the average treatment effect 
on the treated (ATT) on the change in investment for affected firms with rigid wages. Those firms significantly reduce investment by up to 2.5 percentage points relative to unaffected firms in the matched control group. This decrease in investment is larger in magnitude than the investment drop for the full sample of affected firms reported in Table IV. Beginning in the second quarter of 2012, the investment gap for affected firms with rigid wages starts to close and becomes statistically significant and close to zero in magnitude. In contrast, there is no significant drop in investment for affected firms with flexible wages, as shown in Column 2 of Table VI. In line with Schoefer (2015) and Wang (2017), these findings suggests that wage flexibility at the firm level can mitigate the negative effects of restricted access to external finance. Moreover, these results provide corroborating firmlevel evidence for recent findings in the macroeconomic literature on financial frictions that wage rigidities are a necessary feature to create amplification of financial shocks (Ajello, 2016). Columns 3 and 4 of Table VI report the corresponding matching estimation results on firm growth. Consistent with the significant investment gap for affected firms with rigid wages, Column 3 shows a large and persistent growth gap for those firms. Affected firms with rigid wages grow 12.2 percentage points less from 2008-Q3 to 2012-Q3 than unaffected firms in the matched control group. This growth gap remains large and statistically significant until almost the end of the sample period in 2015-Q4. Conversely, and consistent with the respective investment results, the growth gap for affected firms with flexible wages is small in magnitude and statistically insignificant, as shown in Column 4 of Table VI.

[Table VI about here]

Columns 1 and 2 of Table VII report the matching estimation results for the average treatment effect on the treated (ATT) on employment growth for affected firms with rigid and flexible wages, respectively. While only weakly statistically significant, the effect of a credit supply shock on employment growth is negative and large in magnitude for affected firms with rigid wages. Those firms exhibit an additional decline in employment growth of up to 3.6 percentage points between 2011-Q4 and 2012-Q3 compared to unaffected firms in the matched control group. On the other hand, employment effects are slightly positive but insignificant for affected firms with flexible wages. Columns 3 and 4 of Table VII report the corresponding matching estimation results on wage growth. While there are no significant effects on the wage policies of affected firms with rigid wages, Column 
4 shows that affected firms with a low degree of wage rigidity significantly reduce wages in response to a credit supply shock.

[Table VII about here]

Figure 13 plots the estimated treatment effects and trace out the treatment effect curves over time for affected firms with rigid wages. The solid lines represent the matching estimates for the ATT from Columns 1 and 2 of Table VI and Table VII, respectively. The dashed lines represent the corresponding 95\% confidence intervals. The two vertical lines mark 2008-Q4 and 2010-Q1, the beginning and end of the credit crunch period in my sample. The four panels additionally plot the estimated effects for the pre-treatment period, providing a formal test of the parallel trend assumptions. Panel A of Figure 13 illustrates the steep drop in investment and Panel B the resulting large growth gap for affected firms with rigid wags. Panel C and Panel D illustrate how those firms adjust their labor costs following the crisis by reducing employment rather than by lowering wages.

[Figure 13 about here]

Analogously, Figure 14 traces out the treatment effect curves over time for affected firms with flexible wages based on the matching estimates in Columns 3 and 4 of Table VI and Table VII. Panel A of Figure 14 shows that affected firms with flexible wages do not significantly reduce investment in response to a credit supply shock and thus, as shown in Panel B, do not exhibit a significant growth gap in the years following the credit crunch. Panel C and Panel D illustrate how affected firms with flexible wages reduce labor costs by cutting wages while keeping employment stable. Thus, Figure 14 illustrates how wage flexibility at the firm level can mitigate the negative effects of a credit supply shock on investment and firm growth.

[Figure 14 about here]

Finally, Figure 15 compares the treatment effect curves for the full sample with the treatment effect curves for affected firms with rigid wages and affected firms with flexible wages, respectively. The solid black lines represent the matching estimates for the full sample estimated in Section IV; the dashed blue lines represent the corresponding estimates for affected firms with rigid wages; and the dotted red lines represent the corresponding estimates for affected firms with flexible wages. The two vertical lines mark 2008-Q4 and 2010-Q1, the beginning and end of the credit crunch period in 
my sample. Confidence intervals are omitted for clarity. Panel C and Panel D of Figure 15 illustrate the stark difference in the wage and employment responses of affected firms with rigid and flexible wages. Firms with higher levels of wage rigidity reduce labor costs by reducing employment, while firms with low levels of wage rigidity cut wages and keep employment stable.

[Figure 15 about here]

\section{B. Affected Firms with Rigid Wages versus Affected Firms with Flexible Wages}

The previous section suggests that firms with rigid wages adjust their corporate policies differently than firms with flexible wages in response to a credit supply shock. This analysis, however, is subject to the caveat that wage rigidities at the firm level might be correlated with other firm characteristics, in particular firm size. Du Caju, Fuss, and Wintr (2007) find that wage rigidity is much higher for small firms, as large firms usually have firm-level collective wage agreements which enhances wage flexibility. Similarly, Avouyi-Dovi, Fougére, and Gautier (2013) report that negotiating wages is more costly for small firms, resulting in a lower frequency of wage changes. Since large firms are also likely to be less affected by a reduction in bank credit supply, the results in the previous section may merely reflect other differences between affected firms which are correlated with firm size. To alleviate these concerns, I conduct a within treatment group analysis and match affected firms with rigid wages to affected firms with flexible wages to produce a sample of treatment group firms which is balanced in terms of relevant firm characteristics.

Panel A of Table VIII compares the 334 affected firms with rigid wages and the 325 affected firms with flexible wages in the unmatched sample. As expected, and in line with the empirical literature on wage rigidity, firms with a high degree of wage rigidity are significantly smaller than firms with a low degree of wage rigidity. Moreover, the average affected firm with rigid wages has a higher pre-crisis investment ratio, a lower cash flow, and a higher long-term leverage.

[Table VIII about here]

To each of the 334 affected firms with rigid wages, I match one firm from the control group pool of affected firms with flexible wages to produce a balanced sample in terms of the relevant firm characteristics. Panel B of Table VIII shows the mean values of the matching covariates for the two groups of firms after applying the matching procedure. While statistically significant differences 
remain in terms of the return on assets and the long-term leverage, the matched sample is balanced in terms of all other matching covariates, most importantly firm size.

Table IX reports the matching estimation results for the average treatment effect on the treated (ATT) on investment- firm- employment- and wage growth. Column 1 shows that affected firms with rigid wages exhibit an additional decline in investment by up to 2.3 percentage points relative to affected firms with flexible wages. There is a significant investment gap between the two groups of firms for 2 years over the period from 2011-Q2 to 2013-Q1. As shown in Column 2, this temporary investment gap translates into a growth gap of up to 10.2 percentage points 3 years after the crisis. While the growth gap becomes statistically insignificant at the end of the sample period, its magnitude remains large with about 7 percentage points. Columns 3 and 4 of Table IX show how differently firms with rigid and flexible wages adjust their labor policies in response to a credit supply shock. Firms with a higher degree of wage rigidity reduce employment by up to 5.5 percentage points more and wages by up to 2.7 percentage points less than firms with flexible wages.

[Table IX about here]

Figure 16 traces out the treatment effect curves. The solid lines represent the matching estimates for the ATT based on the results in Table IX, and the dashed lines represent the corresponding 95\% confidence intervals. Panel A illustrates how firms with rigid wages reduce investment compared to firms with flexible wages in response to a credit supply shock. As shown in Panel B, this translates into a growth gap which remains large in magnitude until the end of the sample period. Panel C and Panel D illustrate the relative reduction in employment and the relative increase in wages for firms with rigid wages relative to firms with flexible wages.

[Figure 16 about here]

Taken together, these findings provide novel firm-level evidence on the role of wage rigidity for the amplification of financial shocks. Moreover, the results are consistent with the notion of labor hoarding which posits that, if feasible, adjusting wages while retaining workers might put firms in a better position to expand when the economy recovers. Thus, labor hoarding behavior due to wage flexibility might mitigate the negative long-run effects of banking crises. In this regard, the case 
of the Germany economy during and after the financial crisis may provide additional context. ${ }^{18}$ Like the United States, Germany experienced a credit crunch (Puri, Rocholl, and Steffen, 2011) and a similarly severe recession during the 2008-09 financial crisis. However, unlike in the United States, there was virtually no rise in unemployment in Germany during the crisis, an economic development which has been dubbed the "German labor market miracle" (Burda and Hunt, 2011). German GDP also recovered slightly faster to pre-crisis levels than U.S. GDP and significantly faster than the GDP in other major economies (CEA, 2014). The resilience of the German labor market and the fast recovery of the German economy has often been attributed to short-time work ("Kurzarbeit") programs subsidized by the government. ${ }^{19}$ Under short-time work schemes, firms refrain from layoffs but instead reduce workers' hours. Workers are paid the wage for the actual hours worked plus a compensation ("Kurzarbeitergeld") between 60 and 67 percent of the net pay for the hours not demanded. Firms are later reimbursed for the "Kurzarbeitergeld" expenses by the German Federal Employment Agency. During the financial crisis, the German government expanded the short-time work scheme by prolonging the duration of firm subsidies from 6 to 24 months and by reducing the required minimum number of affected workers (Burda and Hunt, 2011). These policy measures effectively constituted an injection of wage flexibility into the German labor market, as firms were able to reduce labor costs by lowering their wage bill without laying off workers. The fast recovery of the German economy following the crisis is consistent with my results that more flexible wages might mitigate the long-run real effects of banking crises.

\section{Robustness Checks}

\section{A. Alternative Definition of the Treatment Period}

In my baseline specification, I define the period from 2008-Q4 to 2010-Q1 as the credit crunch period in the syndicated loan market. During these 6 quarters credit activity in the syndicated loan market was significantly below its long-run average. In this section, I perform a robustness check using a narrower definition of the treatment period, from 2009-Q1 to 2009-Q4. As the credit

\footnotetext{
${ }^{18}$ See Giroud and Mueller (2017) for a similar discussion.

${ }^{19}$ For a discussion of labor hoarding and short-time work in Germany during the financial crisis, see Dietz, Stops, and Wawei (2010), Burda and Hunt (2011), Cahuc and Carcillo (2011), Rinne and Zimmermann (2013), Balleer, Gehrke, Lechthaler, and Merkl (2016), and Giroud and Mueller (2017).
} 
availability in the syndicated loan market was at its lowest in 2009 (Becker and Ivashina, 2014), I expect the results to be stronger using this narrower definition of the treatment period. Table $\mathrm{X}$ presents the results of this robustness check. Column 1 shows that firms more adversely affected by the reduction in aggregate credit supply from 2009-Q1 to 2009-Q4 reduce investment by up to 2.0 percentage points relative to firms in the matched control group over a period of 2 years following the crisis. As shown in Column 2, this temporary investment gap results in a persistent growth gap of 12 percentage points. As expected, both the temporary drop in investment as well as the persistent growth gap are larger in magnitude than for the baseline results in Table IV.

[Table X about here]

\section{B. Alternative Definitions of the Treatment Group}

In my baseline specification, I define the treatment group to be firms which had at least one term loan or credit line maturing during the period from 2008-Q4 to 2010-Q1, and I define the control group pool to be firms which had neither a term loan nor a credit line maturing during this period. This definition of the treatment group is rather conservative and might include firms for which the volume of maturing loans constitutes only a small share of its overall corporate financing. As such firms have lower refinancing risk, they should be only marginally affected by the reduction

in aggregate credit supply. To address this concern, I perform a robustness check and define the treatment group to be firms for which the volume of maturing loans during the credit crunch period exceeds 5 percent (10 percent) of the firm's total assets. The control group pool remains unchanged and consists of firms which had neither a term loan nor a credit line maturing during this period. As firms with a larger volume of maturing loans are expected to be more adversely affected by the reduction in credit supply, I expect the results to be stronger using this stricter definition of the treatment group. Table XI presents the results of this robustness check. Columns 1 and 2 show that firms for which the volume of maturing loans during the credit crunch period exceeds 5 percent (10 percent) of total assets reduce investment by up to 2.0 percentage points ( 2.3 percentage points) relative to firms in the matched control group in the years after the crisis. As shown in Columns 3 and 4, this temporary investment gap results in a persistent growth gap of 10 and 12 percentage points, respectively. As expected, both the temporary drop in investment as well as the persistent 
growth gap are larger in magnitude than for the baseline results in Table IV.

[Table XI about here]

\section{Conclusion}

In this paper I have investigated the long-run effects of a banking crisis on real firm outcomes and how these effects depend on nominal wage rigidities at the firm level. I showed that firms more adversely affected by a reduction in aggregate credit supply reduce investment over a period of 2 years following a credit supply shock before returning to normal levels of investment. As firms do not offset this temporary investment gap, it results in a persistent and significant accumulated growth gap a full 6 years after the initial shock. I also showed that wage rigidities at the firm level significantly exacerbate the negative long-run effects of banking crises. Affected firms with higher levels of wage rigidity exhibit a steeper drop in investment and grow more slowly than affected firms with flexible wages.

Since the financial crisis of 2008-09, a growing literature examines how the economy recovers in the aftermath of banking crises. To date, many important questions remain unresolved. To what extent does the aftermath of banking crises represent a causal relationship between credit market disruptions and economic activity? Do banking crises have persistent negative real effects or is there a full recovery in the long run? And what explains the heterogeneity in the recovery paths following banking crises? While most papers in the existing literature attempt to answer these questions with aggregate data, this approach has several drawbacks. First, identifying exogenous shocks to credit supply is difficult when using aggregate data and, second, "measuring recovery" with aggregate data suffers from the lack of a credible counterfactual of how economic activity would have evolved in the absence of a banking crisis. In the light of these empirical challenges, Romer and Romer (2017) suggest that "the most fruitful approach to establishing causation may lie in combining natural experiments with detailed cross-section evidence." Studying the long-run effects of credit market disruptions on real firm outcomes, my paper provides such quasi-experimental firm-level evidence. 


\section{REFERENCES}

Abadie, Alberto, David Drukker, Jane Leber Herr, and Guido W. Imbens, 2004, Implementing matching estimators for average treatment effects in Stata, Stata Journal 4, 290-311.

Abadie, Alberto, and Guido W. Imbens, 2002, Simple and bias-corrected matching estimators for average treatment effects, NBER Technical Working Paper Series 283, 1-55.

Abadie, Alberto, and Guido W. Imbens, 2006, Large sample properties of matching estimators for average treatment effects, Econometrica 74, 235-267.

Abowd, John M., Bryce E. Stephens, Lars Vilhuber, Fredrik Andersson, Kevin L. McKinney, Marc Roemer, and Simon Woodcock, 2009, The LEHD infrastructure files and the creation of the Quarterly Workforce Indicators, Producer Dynamics: New Evidence from Micro Data 149-230.

Acharya, Viral V., Tim Eisert, Christian Eufinger, and Christian Hirsch, 2016, Real effects of the sovereign debt crisis in europe: Evidence from syndicated loans, Working Paper .

Adrian, Tobias, Paolo Colla, and Hyun Song Shin, 2013, Which financial frictions? Parsing evidence from the financial crisis of 2007 to 2009, NBER Macroeconomics Annual 2012 159-214.

Ajello, Andrea, 2016, Financial intermediation, investment dynamics, and business cycle fluctuations, American Economic Review 106, 2256-2303.

Almeida, Heitor, Murillo Campello, Bruno Laranjeira, and Scott Weisbenner, 2012, Corporate debt maturity and the real effects of the 2007 credit crisis, Critical Finance Review 1, 3-58.

Avouyi-Dovi, Sanvi, Denis Fougére, and Erwan Gautier, 2013, Wage rigidity, collective bargaining, and the minimum wage: Evidence from french agreement data, Review of Economics and Statistics 95, 1337-1351.

Balleer, Almut, Britta Gehrke, Wolfgang Lechthaler, and Christian Merkl, 2016, Does short-time work save jobs? A business cycle analysis, European Economic Review 84, 99-122.

Becker, Bo, and Victoria Ivashina, 2014, Cyclicality of credit supply: Firm level evidence, Journal of Monetary Economics 62, 76-93. 
Belo, Frederico, Xiaoji Lin, and Fan Yang, 2014, External equity financing shocks, financial flows, and asset prices, NBER Working Paper Series 20210.

Bentolila, Samuel, Marcel Jansen, Gabriel Jiménez, and Sonia Ruano, 2015, When credit dries up: Job losses in the Great Recession, CEMFI Working Paper 1310.

Berg, Tobias, Anthony Saunders, and Sascha Steffen, 2016, The total cost of corporate borrowing in the loan market: Don't ignore the fees, Journal of Finance 71, 1357-1392.

Bernanke, Ben S., Mark Gertler, and Simon Gilchrist, 1999, The financial accelerator in a quantitative business cycle model, Handbook of Monetary Economics 1341-1393.

Biddle, Jeff E., 2014, Retrospectives: The cyclical behavior of labor productivity and the emergence of the labor hoarding concept, Journal of Economic Perspectives 28, 197-212.

Brunnermeier, Markus K., Thomas M. Eisenbach, and Yuliy Sannikov, 2012, Macroeconomics with financial frictions: A survey, NBER Working Paper Series 18102.

Burda, Michael C., and Jennifer Hunt, 2011, What explains the German labor market miracle in the Great Recession?, NBER Working Paper Series 17187.

Cahuc, Pierre, and Stéphane Carcillo, 2011, Is short-time work a good method to keep unemployment down?, IZA Discussion Paper Series 5430.

Campello, Murillo, and Erasmo Giambona, 2013, Real assets and capital structure, Journal of Financial Quantitative Analysis 48, 1333-1370.

Campello, Murillo, John R. Graham, and Campbell R. Harvey, 2010, The real effects of financial constraints: Evidence from a financial crisis, Journal of Financial Economics 97, 470-487.

CEA, Council of Economic Advisors, 2014, How we got here: The administration's response to the crisis, Economic Report of the President 2014.

Cerra, Valerie, and Sweta Chaman Saxena, 2008, Growth dynamics: The myth of economic recovery, American Economic Review 98, 439-457.

Chaney, Thomas, David Sraer, and David Thesmar, 2012, The collateral channel: How real estate shocks affect corporate investment, American Economic Review 102, 2381-2409. 
Chava, Sudheer, and Amiyatosh Purnanandam, 2011, The effect of banking crisis on bankdependent borrowers, Journal of Financial Economics 99, 116-135.

Chava, Sudheer, and Michael R. Roberts, 2008, How does financing impact investment? The role of debt covenants, Journal of Finance 63, 2085-2121.

Chodorow-Reich, Gabriel, 2014, The employment effects of credit market disruptions: Firm-level evidence from the 2008 - 9 financial crisis, Quarterly Journal of Economics 129, 1-59.

Christiano, Lawrence J., Roberto Motto, and Massimo Rostagno, 2014, Risk shocks, American Economic Review 104, 27-65.

Cingano, Federico, Francesco Manaresi, and Enrico Sette, 2016, Does credit crunch investment down? New evidence on the real effects of the bank-lending channel, Review of Financial Studies 29, 2737-2773.

Daly, Mary, Bart Hobijn, and Brian Lucking, 2012, Why has wage growth stayed strong?, FRBSF Economic Letter April 2, 2012.

Dell'Ariccia, Giovanni, Enrica Detragiache, and Raghuram Rajan, 2008, The real effect of banking crises, Journal of Financial Intermediation 17, 89-112.

Dickens, William T., Lorenz Goette, Erica L. Groshen, Steinar Holden, Julian Messina, Mark E. Schweitzer, Jarkko Turunen, and Melanie E. Ward, 2007, How wages change: Micro evidence from the international wage flexibility project, Journal of Economic Perspectives 21, 195-214.

Dietz, Martin, Michael Stops, and Ulrich Wawei, 2010, Safeguarding jobs through labour hoarding in germany, Applied Economics Quarterly 56, 125-166.

Du Caju, Philip, Catherine Fuss, and Ladislav Wintr, 2007, Downward wage rigidity for different workers and firms - An evaluation for belgium using the IWFP procedure, ECB Working Paper Series 840.

Duval, Romain, Gee Hee Hong, and Yannick Timmer, 2017, Financial frictions and the great productivity slowdown, IMF Working Paper . 
Fallick, Bruce C., Michael Lettau, and William L. Wascher, 2016, Downward nominal wage rigidity in the United States during and after the Great Recession, Finance and Economics Discussion Series: Board of Governors of the Federal Reserve System 2016-001.

Fatás, Antonio, and Ilian Mihov, 2013, Recoveries, CEPR Discussion Paper Series 9551.

Favara, Giovanni, and Jean Imbs, 2015, Credit supply and the price of housing, American Economic Review 105, 958-992.

Friewald, Nils, Rainer Jankowitsch, and Marti G. Subrahmanyam, 2012, Illiquidity or credit deterioration: A study of liquidity in the us corporate bond market during financial crises, Journal of Financial Economics 105, 18-36.

Garicano, Luis, and Claudia Steinwender, 2016, Survive another day: Using changes in the composition of investments to measure the cost of credit constraints, Review of Economics and Statistics 98, 913-924.

Giroud, Xavier, and Holger M. Mueller, 2017, Firm leverage, consumer demand, and employment losses during the great recession, Quarterly Journal of Economics 132, 271-316.

Gropp, Reint, Thomas Mosk, Steven Ongena, and Carlo Wix, 2016, Bank response to higher capital requirements: Evidence from a quasi-natural experiment, SAFE Working Paper Series 156.

IMF, 2016, 2016 Article IV consultation - Press release; staff report; and statement by the executive director for italy, IMF Country Report 22.

Ivashina, Victoria, and David Scharfstein, 2010, Bank lending during the financial crisis of 2008, Journal of Financial Economics 97, 319-338.

Jermann, Urban, and Vincenzo Quadrini, 2012, Macroeconomic effects of financial shocks, American Economic Review 102, 238-271.

Jordà, Oscar, 2005, Estimation and inference of impulse responses by local projections, American Economic Review 95, 161-182.

Jordà, Oscar, Björn Richter, Moritz Schularick, and Alan M. Taylor, 2017, Bank capital redux: Solvency, liquidity, and crisis, NBER Working Paper Series 23287. 
Jordà, Oscar, Moritz Schularick, and Alan M. Taylor, 2013, When credit bites back, Journal of Money, Credit, and Banking 45, 3-28.

Kacperczyk, Marcin, and Philipp Schnabl, 2010, When safe proved risky: Commercial paper during the financial crisis of 2007-2009, Journal of Economic Perspectives 24, 29-50.

Kahle, Kathleen M., and René M. Stulz, 2013, Access to capital, investment, and the financial crisis, Journal of Financial Economics 110, 280-299.

Klasa, Sandy, William F. Maxwell, and Hernán Ortiz-Molina, 2009, The strategic use of corporate cash holdings in collective bargaining with labor unions, Journal of Financial Economics 92, $421-442$.

Kuehn, Lars-Alexander, Mikhail Simutin, and Jessie Jiaxu Wang, 2017, A labor capital asset pricing model, Journal of Finance forthcoming.

Mian, Atif, Amir Sufi, and Emil Verner, 2017, Household debt and business cycles worldwide, Quarterly Journal of Economics forthcoming.

Ouimet, Paige, and Elena Simintzi, 2017, Wages and firm performance: Evidence from the 2008 financial crisis, Working Paper .

Papell, David H., and Ruxandra Prodan, 2012, The statistical behavior of GDP after financial crises and severe recessions, The B.E. Journal of Macroeconomics, Special Issue: Long-Term Effects of the Great Recession 12, 1-29.

Peek, Joe, and Eric S. Rosengren, 2000, Collateral damage: Effects of the Japanese bank crisis on real activity in the United States, American Economic Review 90, 30-45.

Pischke, Jörn-Steffen, 2016, Wage flexibility and employment fluctuations: Evidence from the housing sector, NBER Working Paper Series 22496.

Puri, Manju, Jörg Rocholl, and Sascha Steffen, 2011, Global retail lending in the aftermath of the US financial crisis: Distinguishing between supply and demand effects, Journal of Financial Economics 100, 556-578. 
Reinhart, Carmen M., and Kenneth S. Rogoff, 2009a, The aftermath of financial crises, American Economic Review 99, 466-472.

Reinhart, Carmen M., and Kenneth S. Rogoff, 2009b, This Time Is Different: Eight Centuries of Financial Folly (Princeton University Press).

Reinhart, Carmen M., and Kenneth S. Rogoff, 2014, Recovery from financial crises: Evidence from 100 episodes, American Economic Review 104, 50-55.

Rinne, Ulf, and Klaus F. Zimmermann, 2013, Is Germany the north star of labor market policy?, IMF Economic Review 61, 702-739.

Romer, Christina D., and David H. Romer, 2017, New evidence on the aftermath of financial crises in advanced countries, American Economic Review 107, 3072-3118.

Schoefer, Benjamin, 2015, The financial channel of wage rigidity, Working Paper .

Schwert, Michael, 2017, Bank capital and lending relationships, Journal of Finance, forthcoming .

Sufi, Amir, 2007, Information asymmetry and financing arrangements: Evidence from syndicated loans, Journal of Finance 67, 629-668.

Tuzel, Selale, and Miao Ben Zhang, 2017, Local risk, local factors, and asset prices, Journal of Finance 72, 325-369.

Wang, Yicheng, 2017, Can wage dynamics in long-term employment relationships help mitigate financial shocks?, Working Paper . 


\section{Appendix A: Figures}

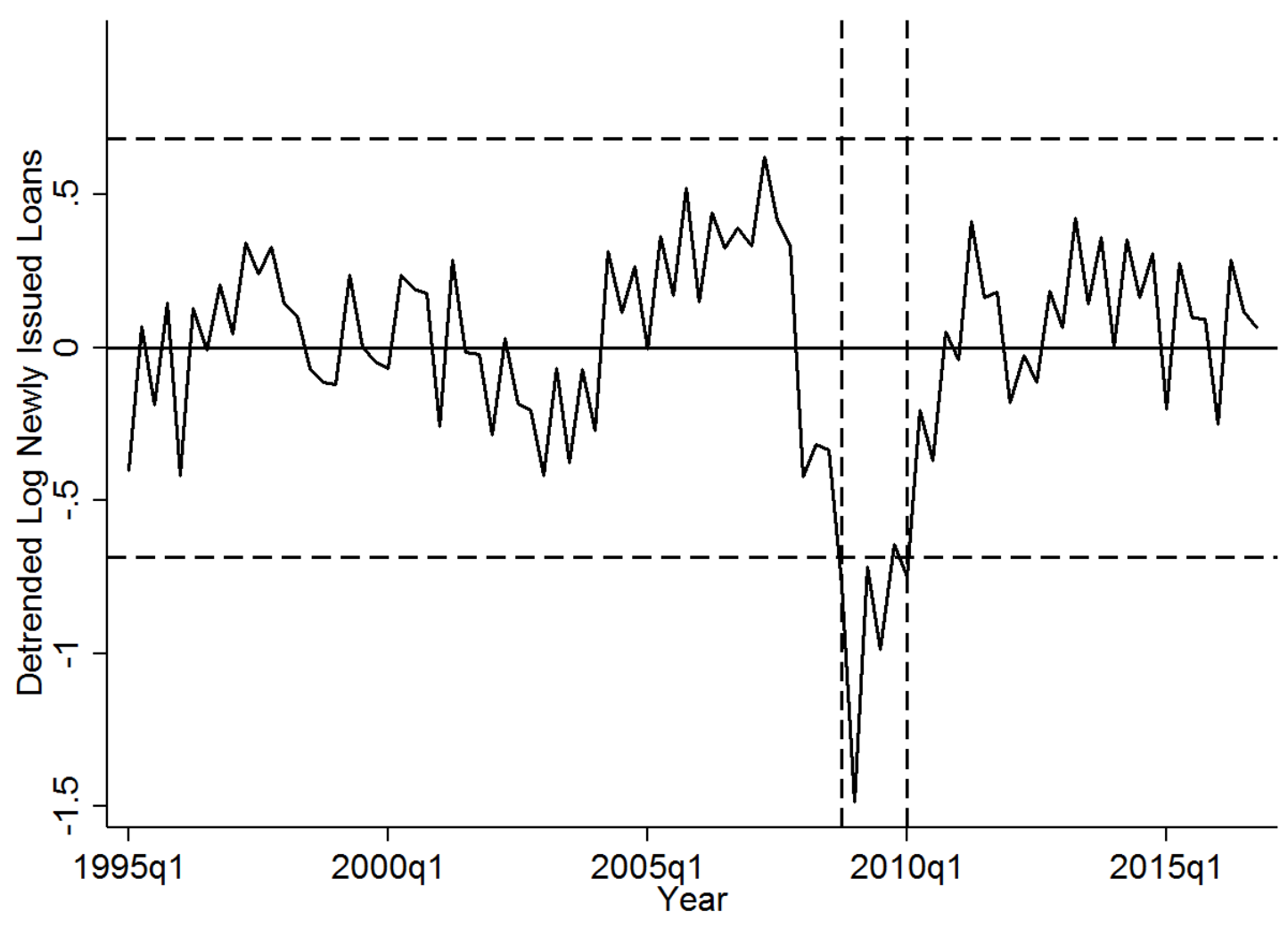

Figure 1. Newly Issued Loans By Quarter. This figure shows the detrended quarterly total log volume of newly issued term loans and credit lines to U.S. nonfinancial borrowers over the period from 1995 to 2016. The two horizontal lines denote two standard deviations around the mean volume of newly originated loans over the whole period. The two vertical lines mark the quarters 2008-Q4 and 2010-Q1, the period during which credit activity fell significantly below the long-run average of loan originations. This time window defines the credit crunch period in the syndicated loan market, which I use as the treatment period in this paper. 


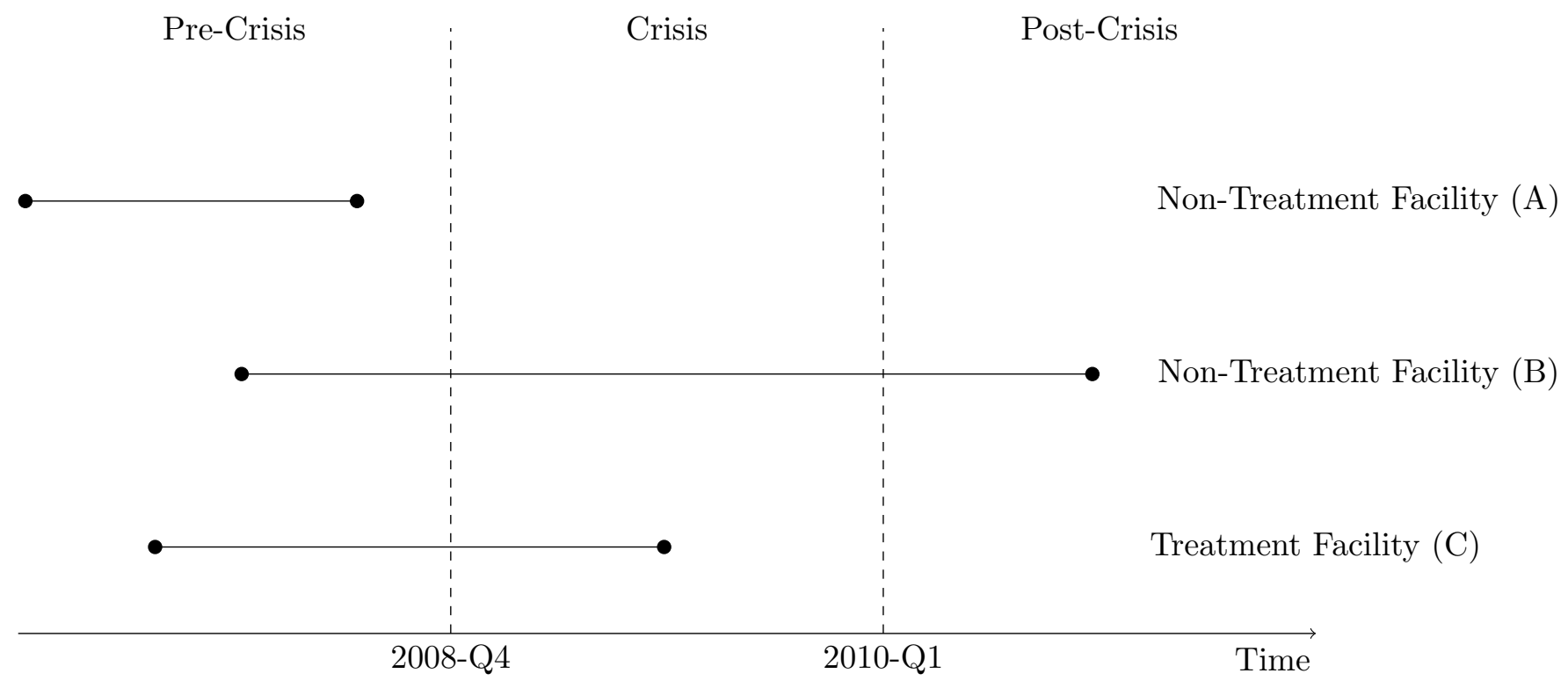

Figure 2. Basic Identification Idea. This figure illustrates the basic idea behind my identification strategy. I split the loan facilities in my sample into Non-Treatment Facilities maturing either before (Facilty A) or after (Facility B) the credit crunch period, and Treatment Facilities maturing during the credit crunch period between 2008-Q4 and 2010-Q1. I define my treatment group to be firms with at least one treatment facility maturing during the credit crunch period. 


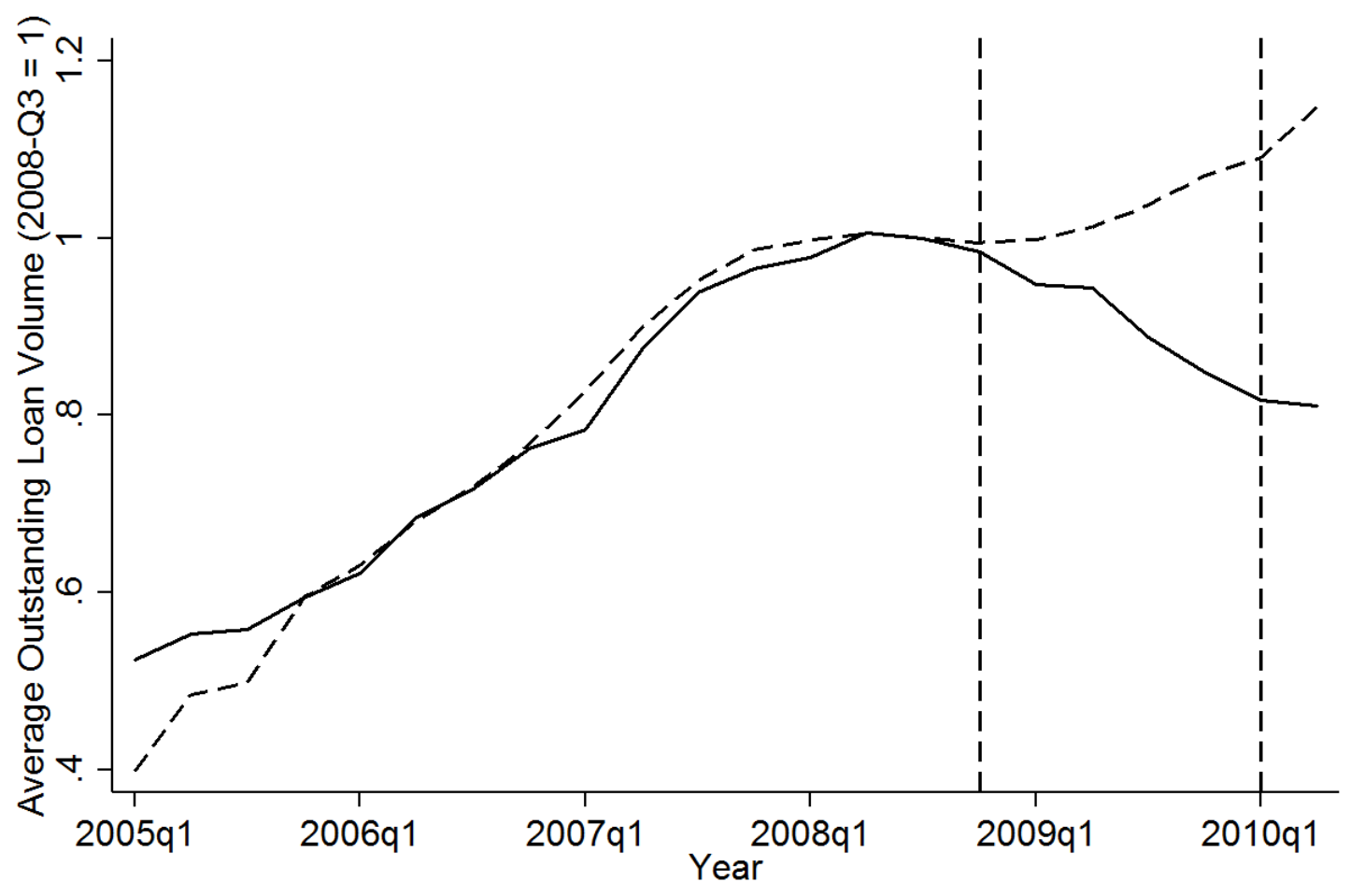

Treatment Firms $\quad-----$ Control Firms

Figure 3. Mean Outstanding Syndicated Loan Volumes By Quarter. This figure shows the evolution of mean outstanding syndicated loan volumes for both treated firms (solid line) and non-treated firms (dashed line), relative to 2008-Q3. Treated firms are firms which have at least one term loan maturing or credit line expiring during the period from 2008-Q4 to 2010-Q1, while non-treated firms have neither a term loan maturing nor credit line expiring during this period. The two vertical lines mark 2008-Q4 and 2010-Q1, the beginning and end of the credit crunch period in my sample. 


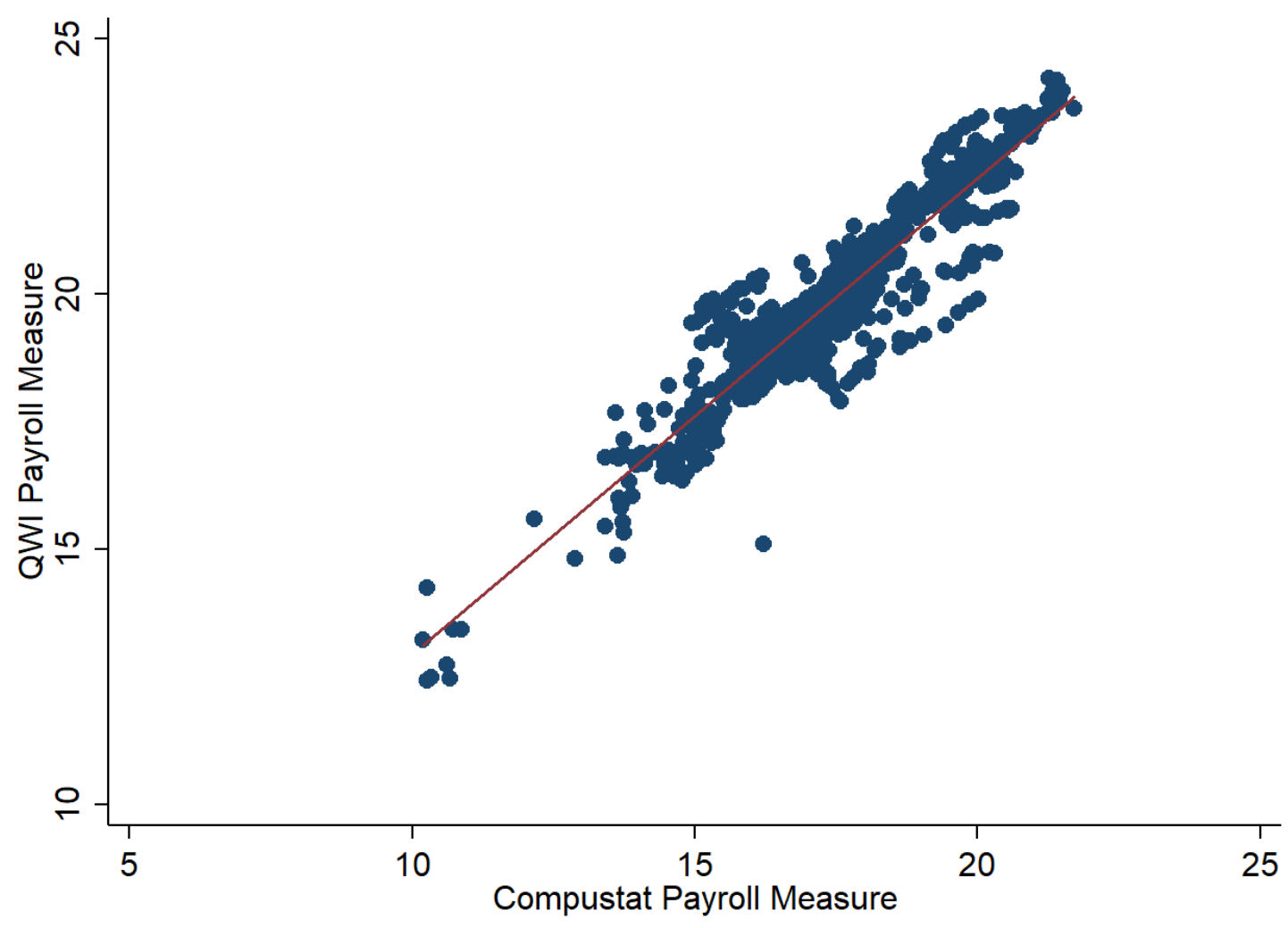

Figure 4. Combined QWI-Compustat Payroll Measure versus Compustat Staff Expenses. This figure plots the logarithm of the combined QWI-Compustat payroll measure as defined in Section III against the logarithm of the Compustat staff expense item XLR for firms for which both data sources are available. The slope coefficient of the associated regression is 0.93 and the adjusted $R^{2}$ is 0.88 , indicating that the combined QWI-Compustat payroll measure provides a reasonable approximation for firms' actual payroll expenses. 


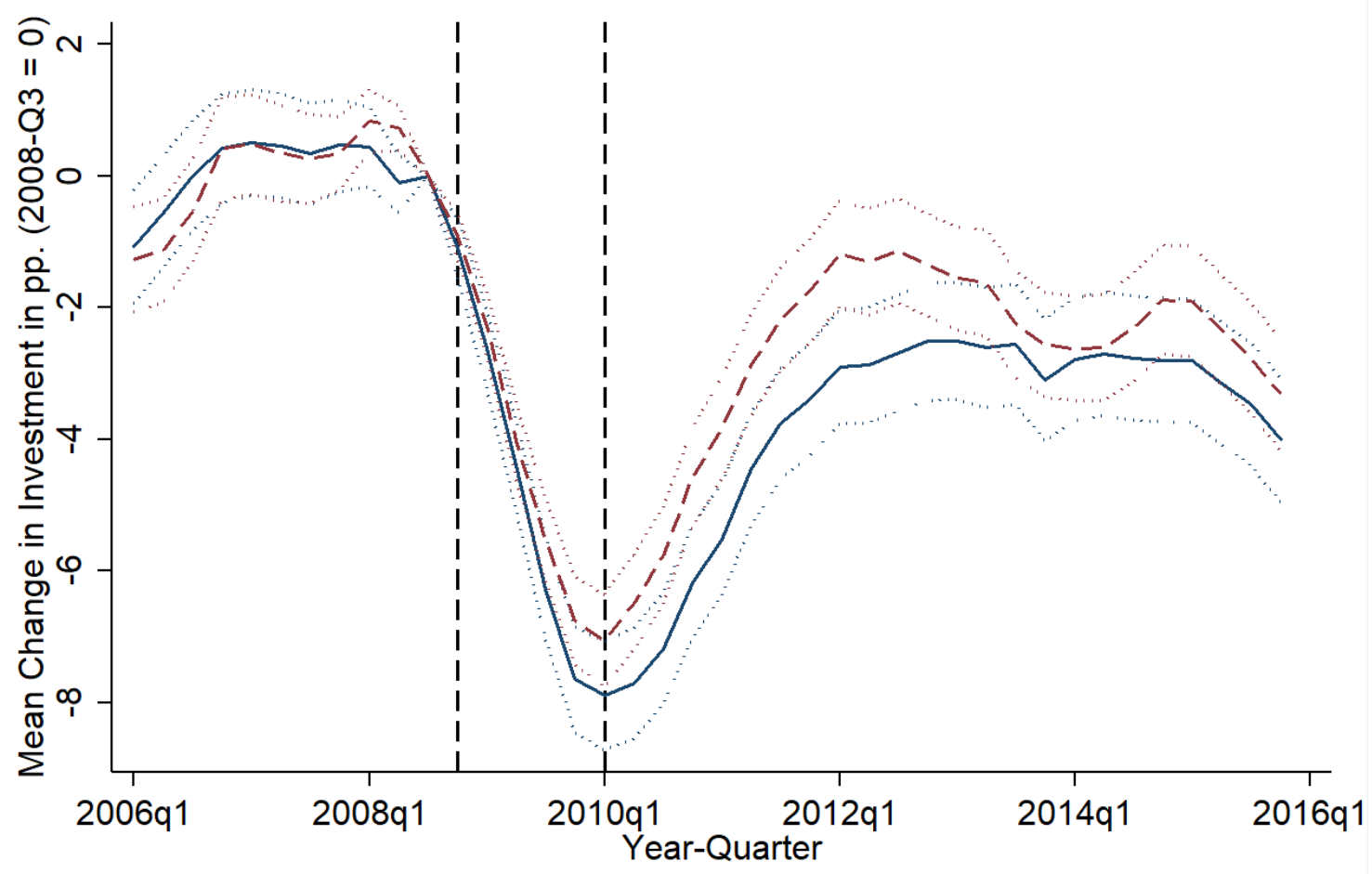

Treatment Firms - - - - - Matched Control Group

Figure 5. Mean Change in Investment Ratios Over Time. This figure shows the evolution of the mean change in investment ratios relative to 2008-Q3 over time for both treated firms (solid blue line) and matched control firms (dashed red line). Treated firms are firms which have at least one term loan maturing or credit line expiring during the period from 2008-Q4 to 2010-Q1, while non-treated firms in the matched control group have neither a term loan maturing nor credit line expiring during this period. The two vertical lines mark 2008-Q4 and 2010-Q1, the beginning and end of the credit crunch period in my sample. The dotted lines mark the $95 \%$ confidence intervals. 


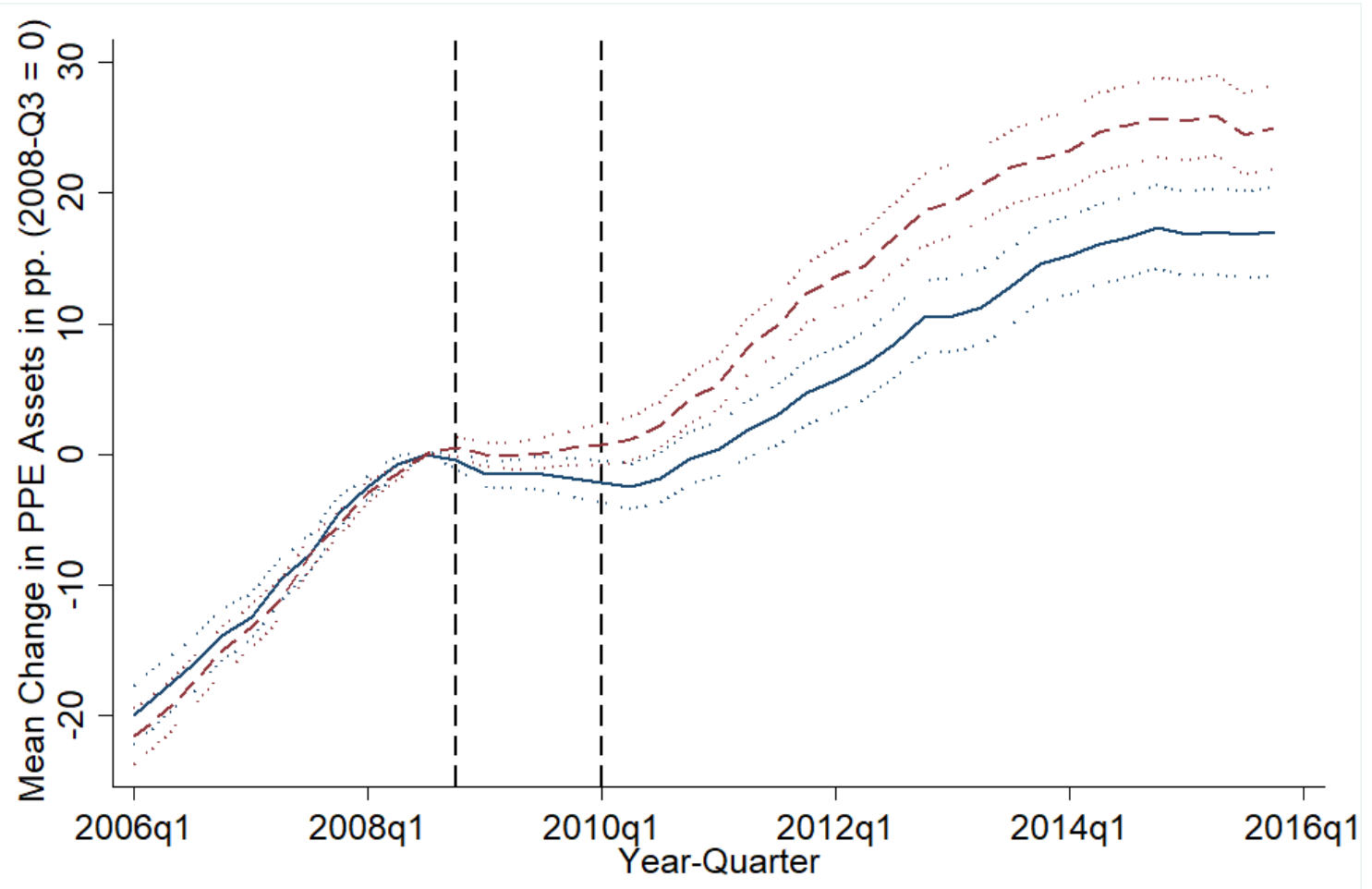

Treatment Firms $\quad-----$ Matched Control Group

Figure 6. Mean Firm Growth Over Time. This figure shows the evolution of the mean change in the logarithm of property, plant, and equipment (PPE) assets relative to 2008-Q3 over time for both treated firms (solid blue line) and matched control firms (dashed red line). Treated firms are firms which have at least one term loan maturing or credit line expiring during the period from 2008-Q4 to 2010-Q1, while non-treated firms in the matched control group have neither a term loan maturing nor credit line expiring during this period. The two vertical lines mark 2008-Q4 and 2010-Q1, the beginning and end of the credit crunch period in my sample. The dotted lines mark the $95 \%$ confidence intervals. 


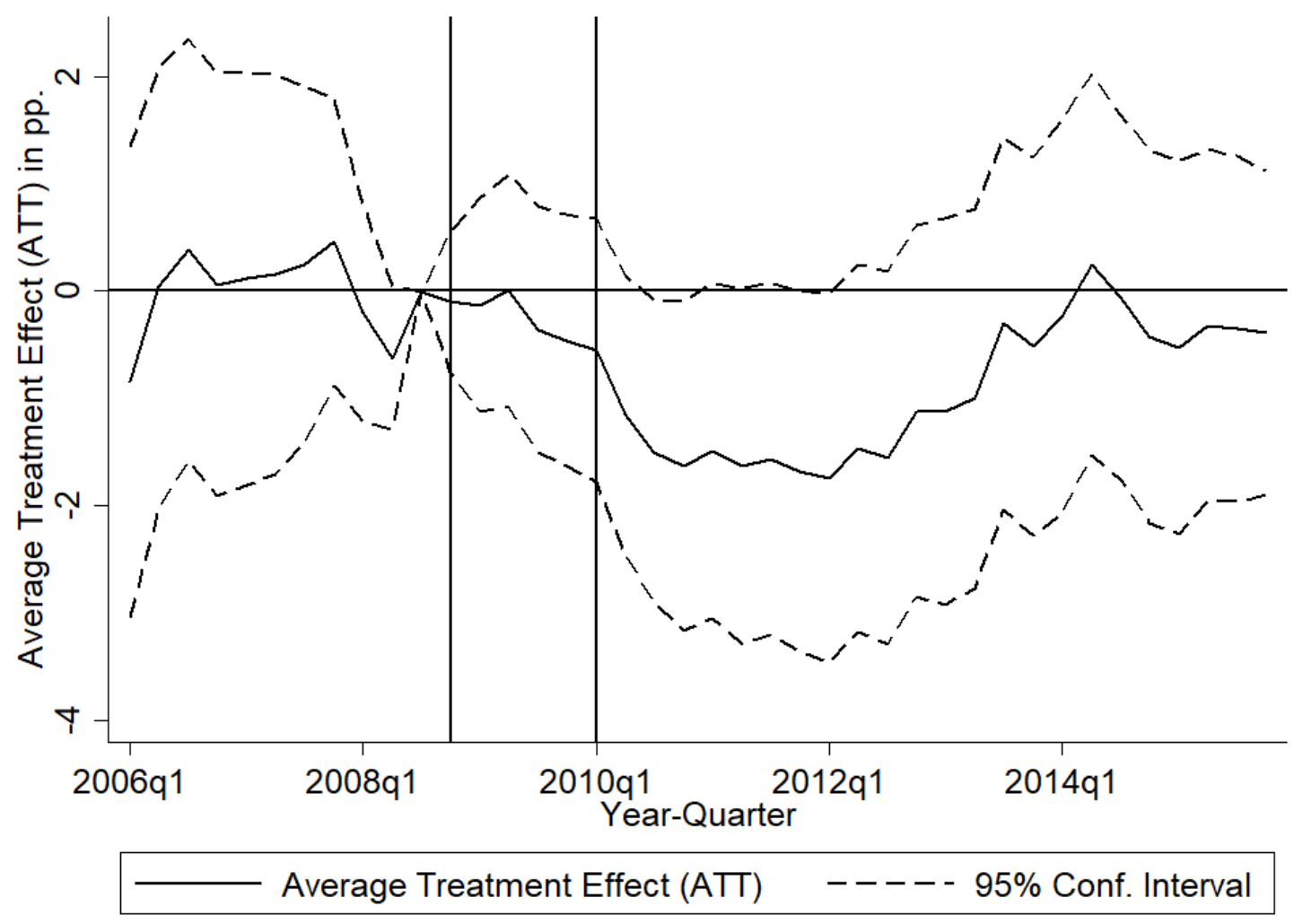

Figure 7. Investment: Treatment Effect Curve Over Time. This figure shows the average treatment effect on the treated (ATT) on the change in investment between 2008-Q3 (the last quarter before the credit supply shock) and multiple pre- and post periods from 2006-Q1 to 2015Q4. Treated firms are firms which have at least one term loan maturing or credit line expiring during the period from 2008-Q4 to 2010-Q1, while non-treated firms in the matched control group have neither a term loan maturing nor credit line expiring during this period. The solid line represents the matching estimates for the ATT based on the results in Table IV. The two dashed lines represent the 95\% confidence intervals. The two vertical lines mark 2008-Q4 and 2010-Q1, the beginning and end of the credit crunch period in my sample. 


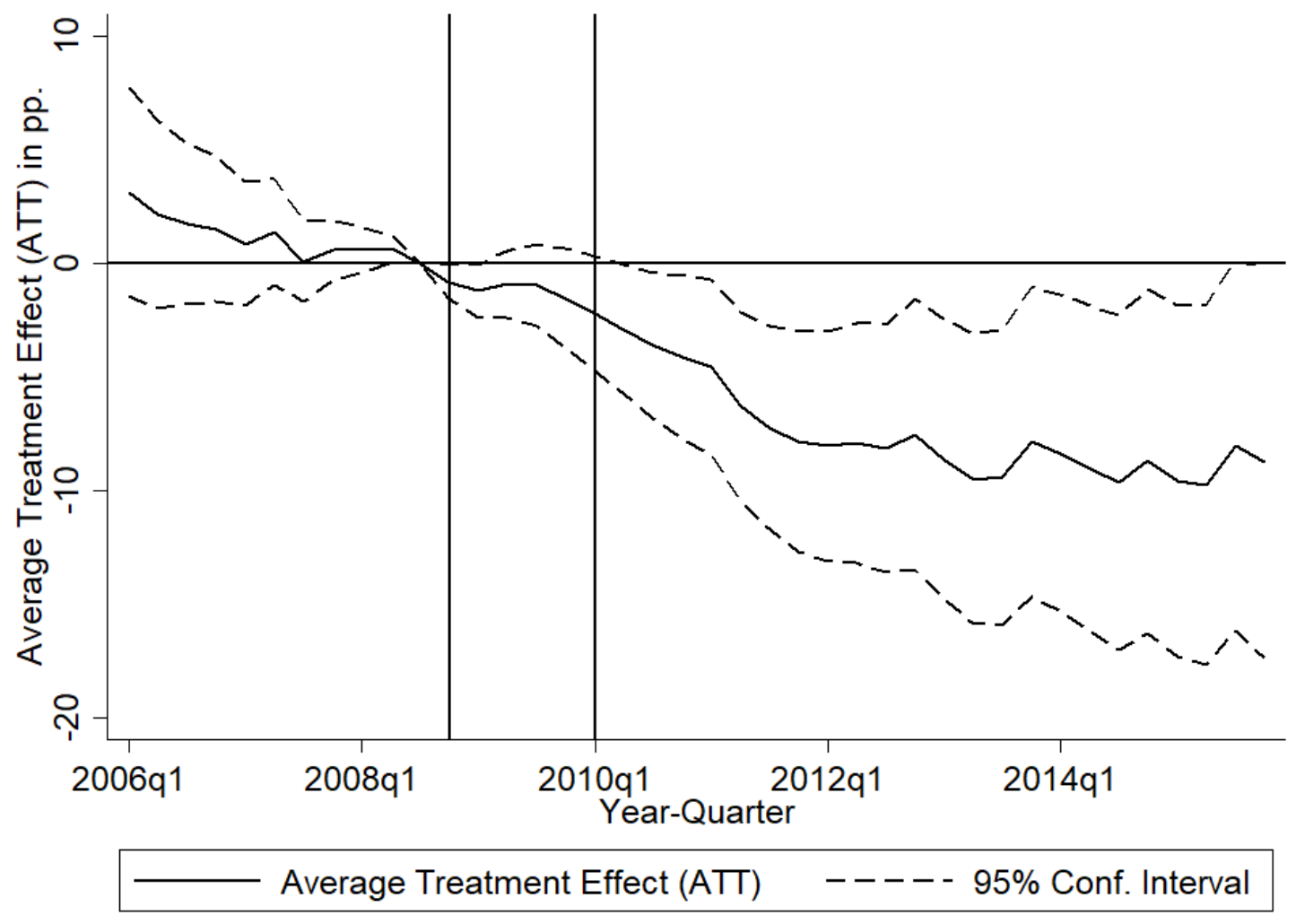

Figure 8. Firm Growth: Treatment Effect Curve Over Time. This figure shows the average treatment effect on the treated (ATT) on the change in the logarithm of property, plant, and equipment (PPE) assets between 2008-Q3 (the last quarter before the credit supply shock) and multiple pre- and post periods from 2006-Q1 to 2015-Q4. Treated firms are firms which have at least one term loan maturing or credit line expiring during the period from 2008-Q4 to 2010-Q1, while non-treated firms in the matched control group have neither a term loan maturing nor credit line expiring during this period. The solid line represents the matching estimates for the ATT based on the results in Table IV. The two dashed lines represent the $95 \%$ confidence intervals. The two vertical lines mark 2008-Q4 and 2010-Q1, the beginning and end of the credit crunch period in my sample. 


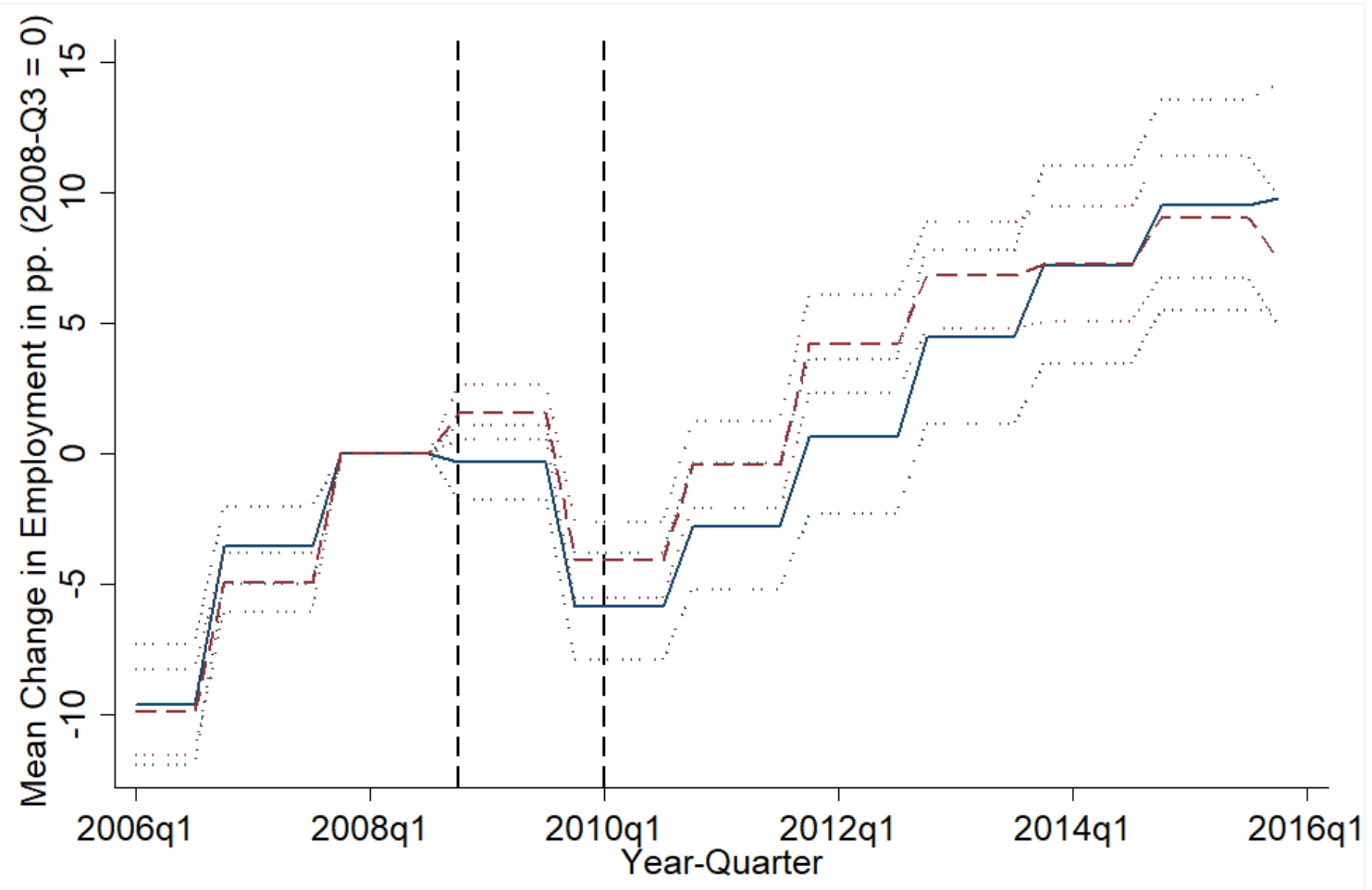

Treatment Firms - - - -- Matched Control Group

Figure 9. Mean Employment Growth Over Time. This figure shows the evolution of the mean change in the logarithm of employment relative to 2008-Q3 over time for both treated firms (solid blue line) and matched control firms (dashed red line). Treated firms are firms which have at least one term loan maturing or credit line expiring during the period from 2008-Q4 to 2010-Q1, while non-treated firms in the matched control group have neither a term loan maturing nor credit line expiring during this period. The two vertical lines mark 2008-Q4 and 2010-Q1, the beginning and end of the credit crunch period in my sample. The dotted lines mark the $95 \%$ confidence intervals. 


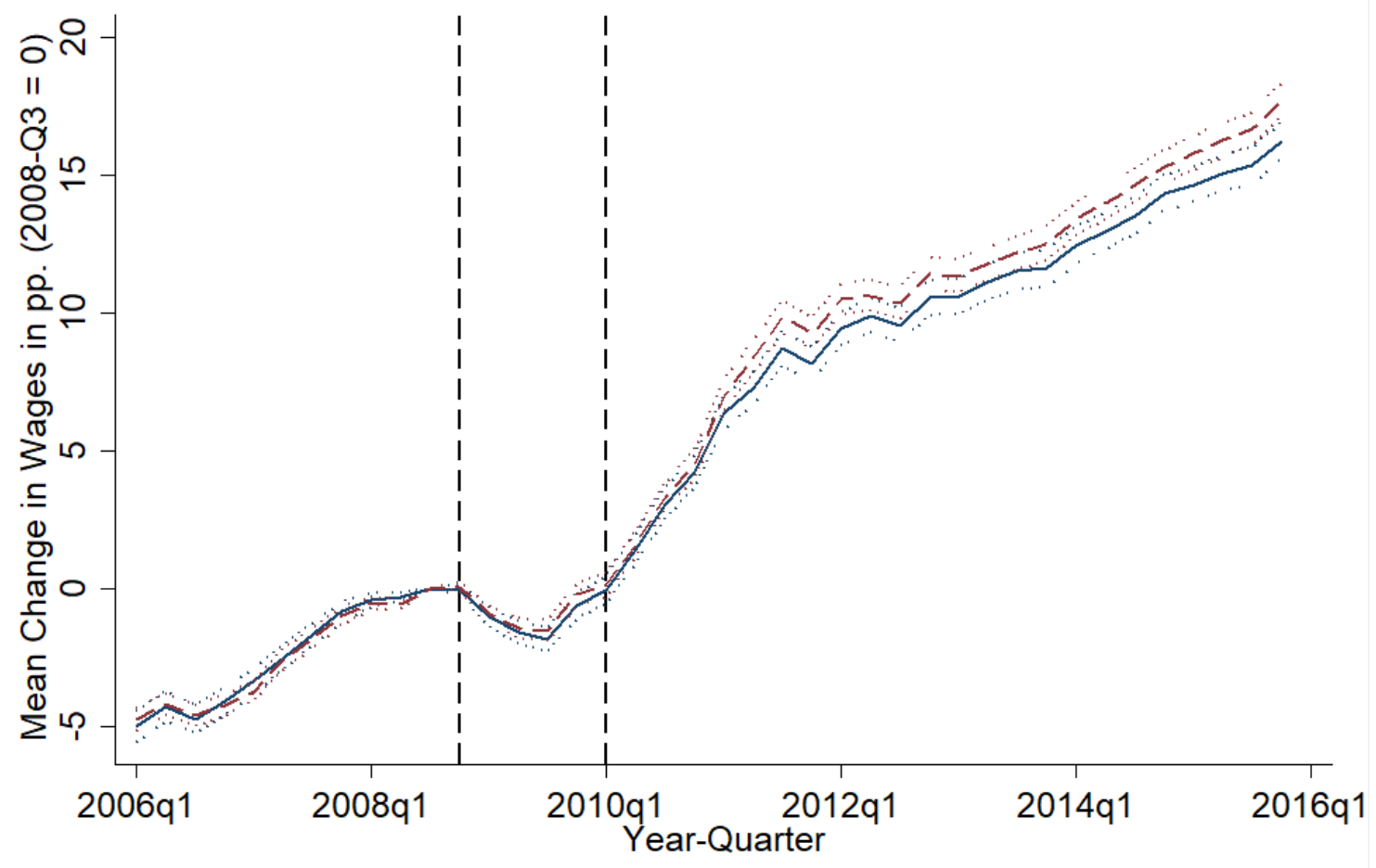

Treatment Firms - - - - - Matched Control Group

Figure 10. Mean Wage Growth Over Time. This figure shows the evolution of the mean change in the logarithm of wages relative to 2008-Q3 over time for both treated firms (solid blue line) and matched control firms (dashed red line). Treated firms are firms which have at least one term loan maturing or credit line expiring during the period from 2008-Q4 to 2010-Q1, while non-treated firms in the matched control group have neither a term loan maturing nor credit line expiring during this period. The two vertical lines mark 2008-Q4 and 2010-Q1, the beginning and end of the credit crunch period in my sample. The dotted lines mark the $95 \%$ confidence intervals. 


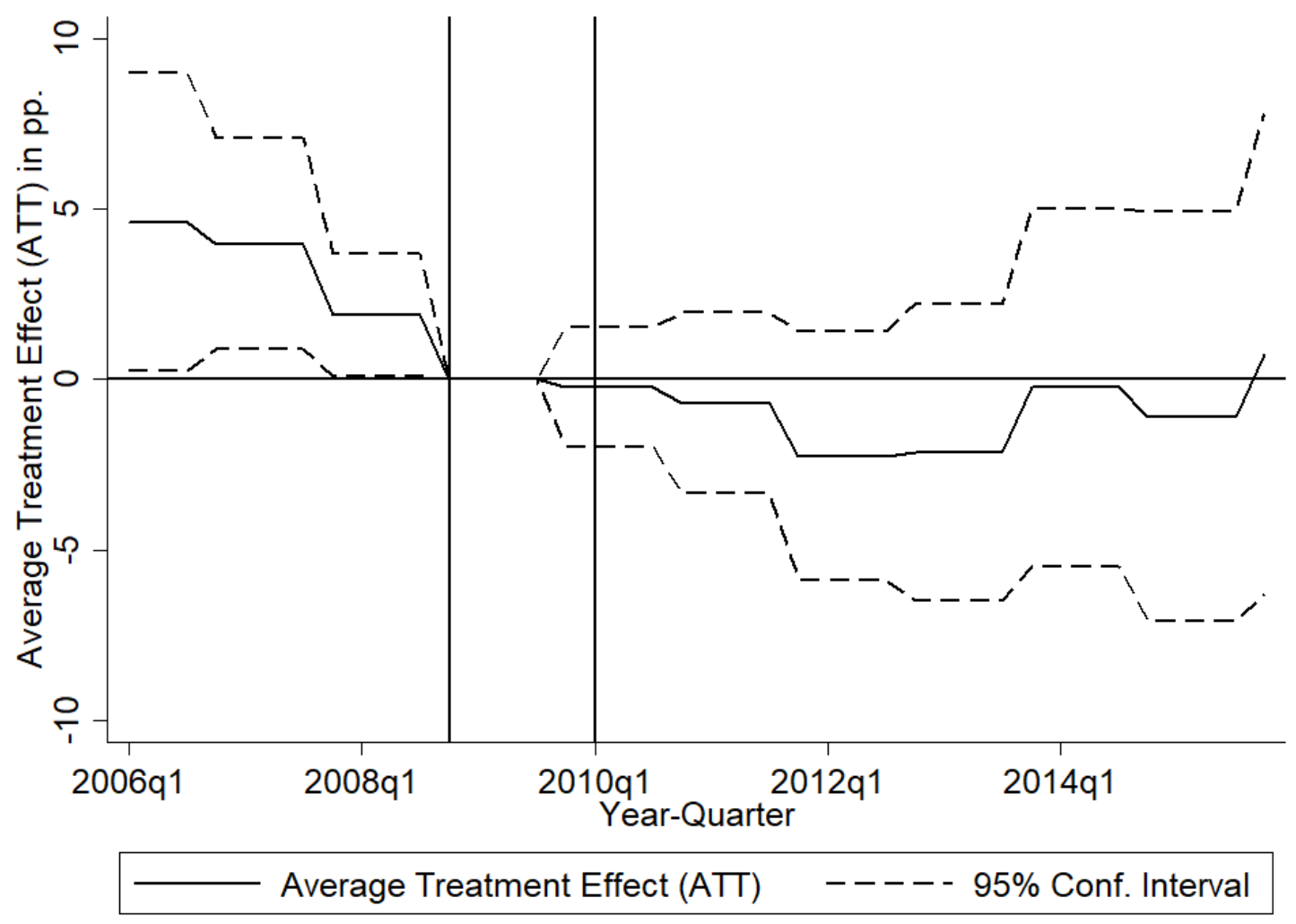

Figure 11. Employment Growth: Treatment Effect Curve Over Time. This figure shows the average treatment effect on the treated (ATT) on the change in the logarithm of employment between 2008-Q3 (the last quarter before the credit supply shock) and multiple pre- and post periods from 2006-Q1 to 2015-Q4. Treated firms are firms which have at least one term loan maturing or credit line expiring during the period from 2008-Q4 to 2010-Q1, while non-treated firms in the matched control group have neither a term loan maturing nor credit line expiring during this period. The solid line represents the matching estimates for the ATT based on the results in Table $\mathrm{V}$. The two dashed lines represent the $95 \%$ confidence intervals. The two vertical lines mark 2008-Q4 and 2010-Q1, the beginning and end of the credit crunch period in my sample. 


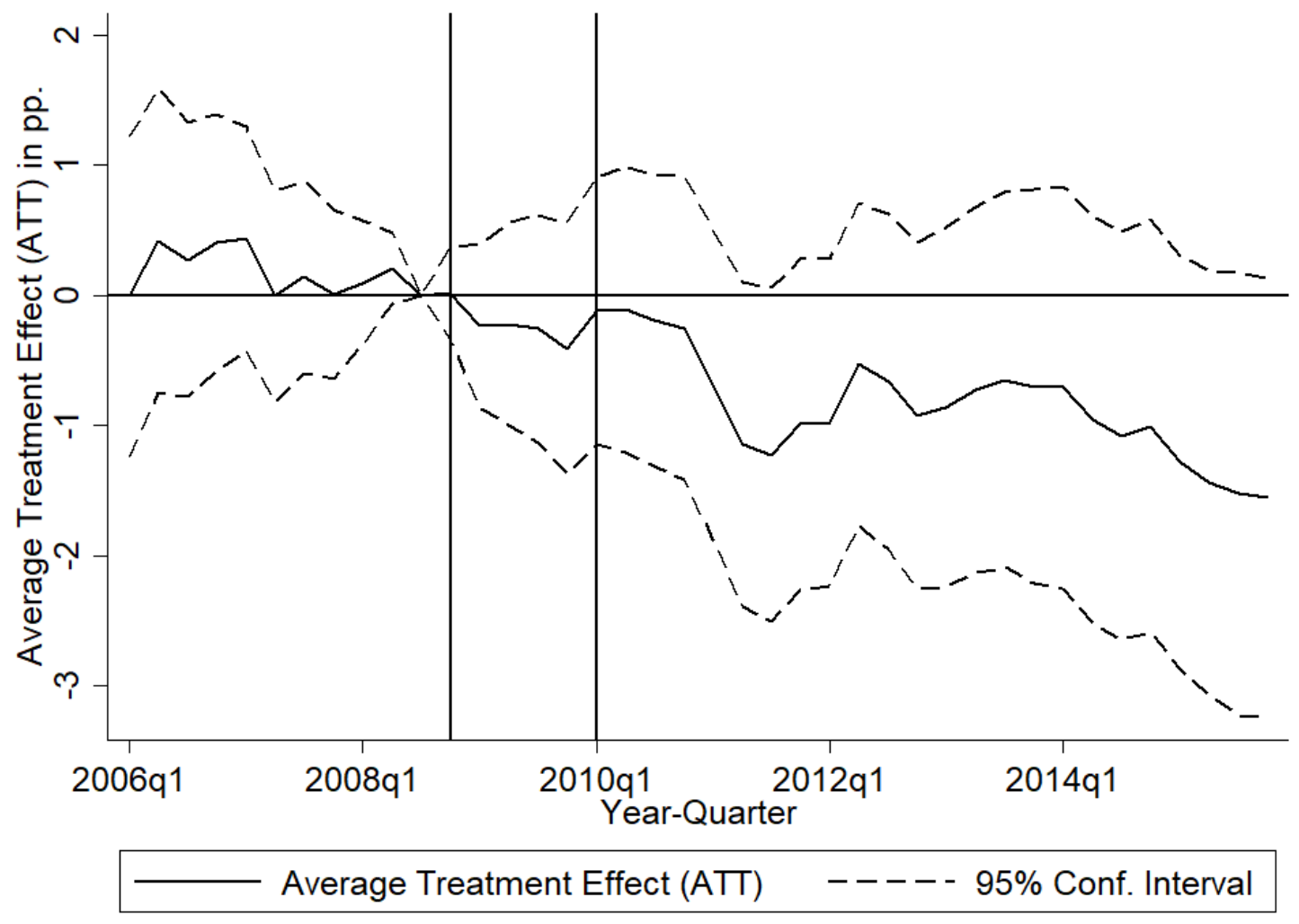

Figure 12. Wage Growth: Treatment Effect Curve Over Time. This figure shows the average treatment effect on the treated (ATT) on the change in the logarithm of wages between 2008-Q3 (the last quarter before the credit supply shock) and multiple pre- and post periods from 2006-Q1 to 2015-Q4. Treated firms are firms which have at least one term loan maturing or credit line expiring during the period from 2008-Q4 to 2010-Q1, while non-treated firms in the matched control group have neither a term loan maturing nor credit line expiring during this period. The solid line represents the matching estimates for the ATT based on the results in Table V. The two dashed lines represent the $95 \%$ confidence intervals. The two vertical lines mark 2008-Q4 and 2010-Q1, the beginning and end of the credit crunch period in my sample. 
(A) Investment

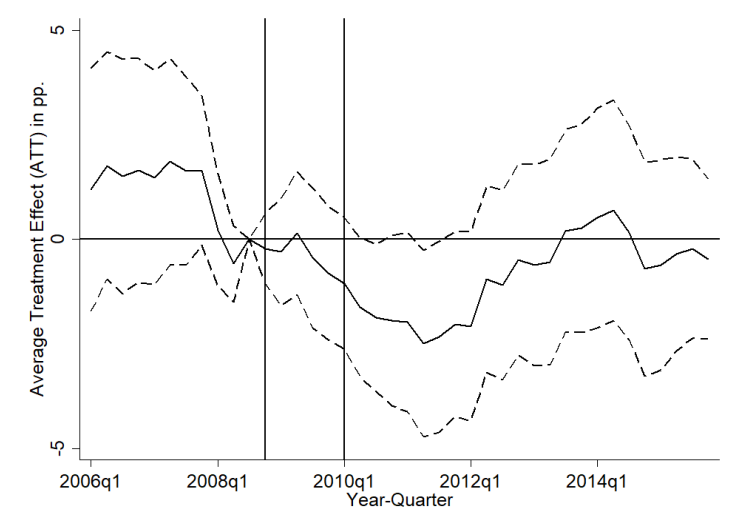

(C) Employment

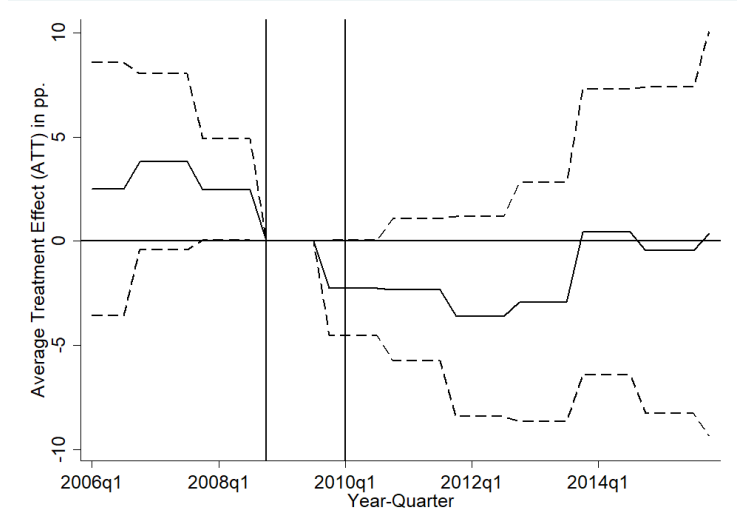

(B) Firm Growth

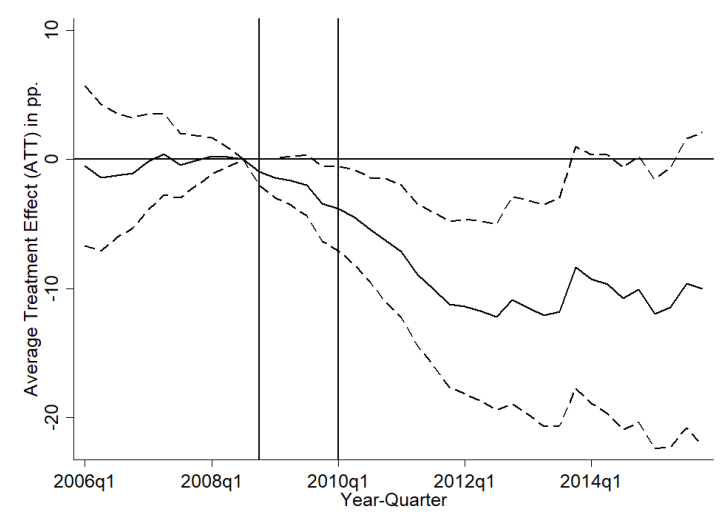

(D) Wages

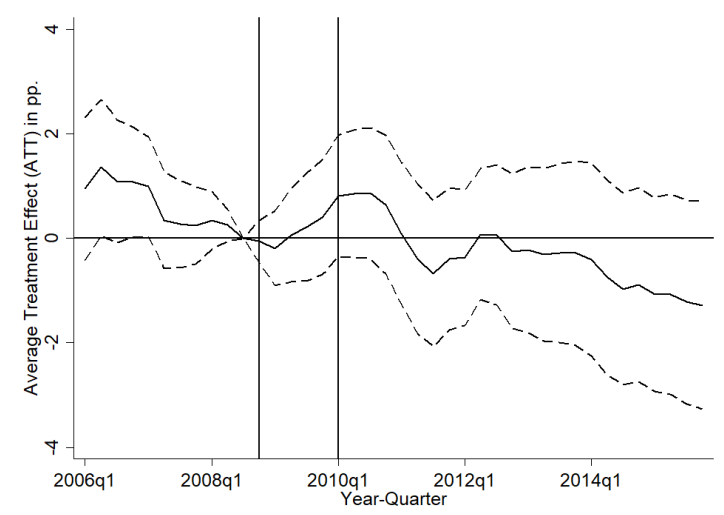

Figure 13. Affected Firms With Rigid Wages: Treatment Effect Curves Over Time. This figure shows the average treatment effect on the treated (ATT) on the change in investment (Panel A), the change in the logarithm of property, plant, and equipment (PPE) assets (Panel B), the change in the logarithm of employment (Panel $\mathrm{C}$ ), and the change in the logarithm of wages (Panel D) between 2008-Q3 (the last quarter before the credit supply shock) and multiple preand post periods from 2006-Q1 to 2015-Q4. Treated firms are firms which have at least one term loan maturing or credit line expiring during the period from 2008-Q4 to 2010-Q1 and which have a below-median wage share of payroll adjustment, while non-treated firms in the matched control group have neither a term loan maturing nor credit line expiring during this period. The solid lines in each panel represents the matching estimates for the ATT based on the corresponding results in Table VI and Table VII. The two dashed lines in each panel represent the $95 \%$ confidence intervals. The two vertical lines in each panel mark 2008-Q4 and 2010-Q1, the beginning and end of the credit crunch period in my sample. 
(A) Investment

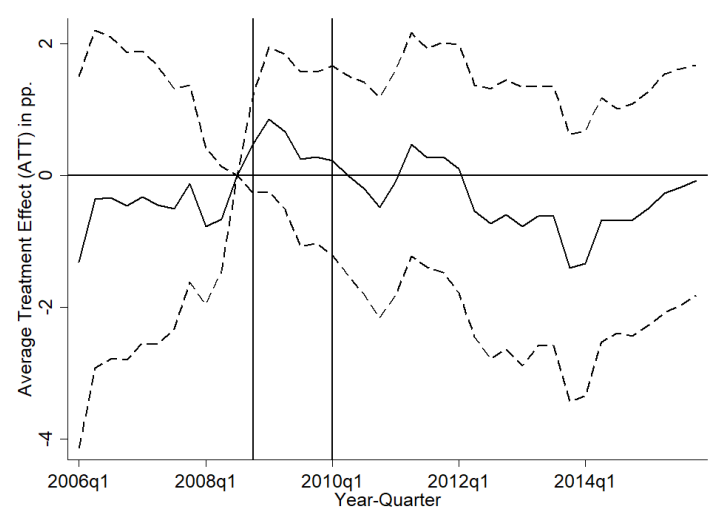

(C) Employment

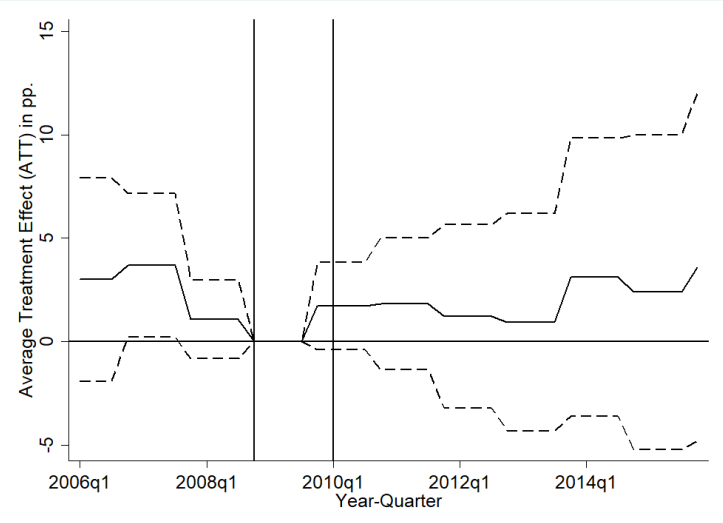

(B) Firm Growth

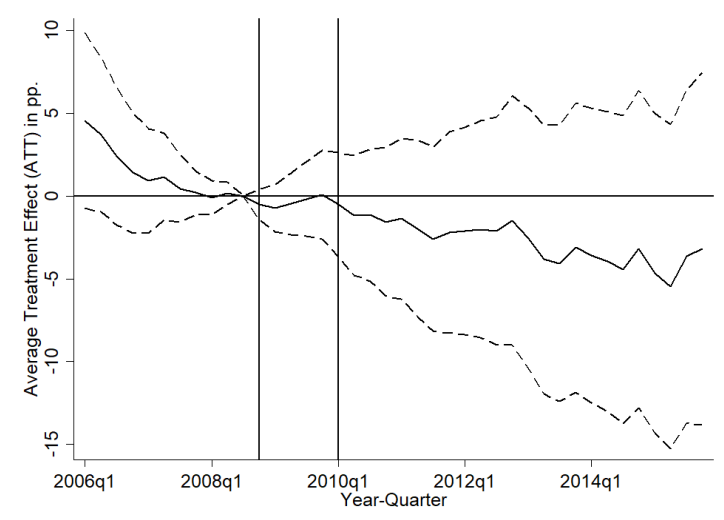

(D) Wages

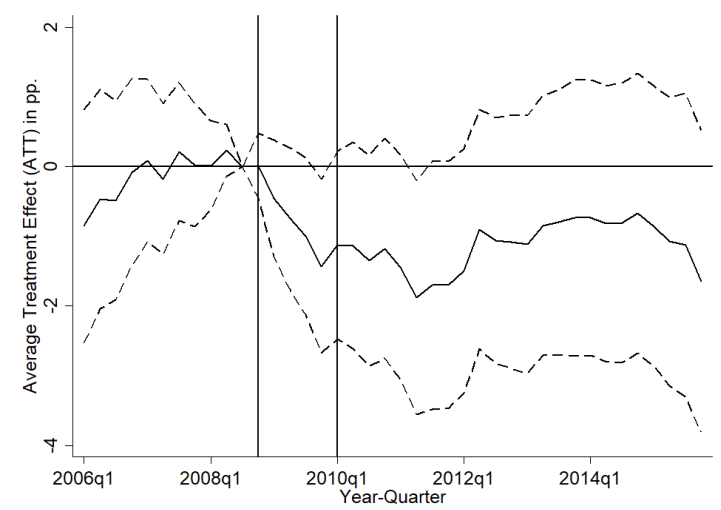

Figure 14. Affected Firms With Flexible Wages: Treatment Effect Curves Over Time. This figure shows the average treatment effect on the treated (ATT) on the change in investment (Panel A), the change in the logarithm of property, plant, and equipment (PPE) assets (Panel B), the change in the logarithm of employment (Panel $\mathrm{C}$ ), and the change in the logarithm of wages (Panel D) between 2008-Q3 (the last quarter before the credit supply shock) and multiple pre- and post periods from 2006-Q1 to 2015-Q4. Treated firms are firms which have at least one term loan maturing or credit line expiring during the period from 2008-Q4 to 2010-Q1 and which have an above-median wage share of payroll adjustment, while non-treated firms in the matched control group have neither a term loan maturing nor credit line expiring during this period. The solid line in each panel represents the matching estimates for the ATT based on the corresponding results in Table VI and Table VII. The two dashed lines in each panel represent the $95 \%$ confidence intervals. The two vertical lines in each panel mark 2008-Q4 and 2010-Q1, the beginning and end of the credit crunch period in my sample. 
(A) Investment

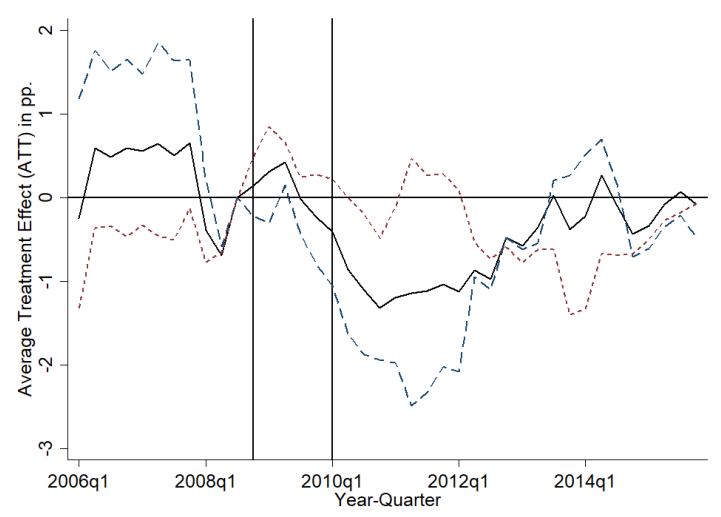

(C) Employment

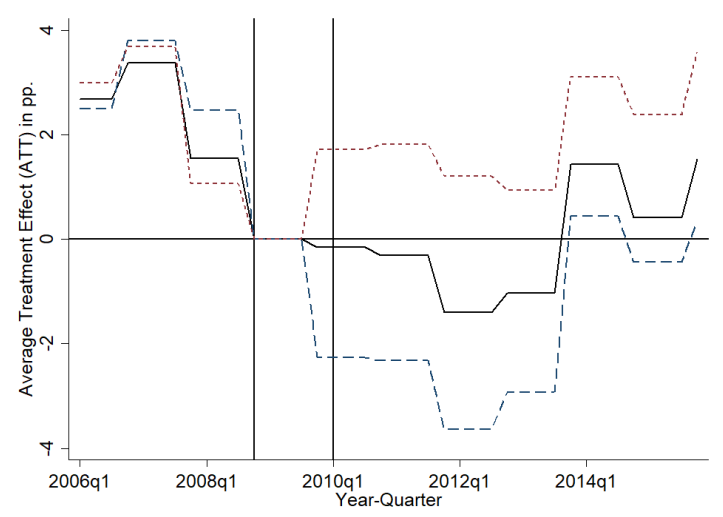

(B) Firm Growth

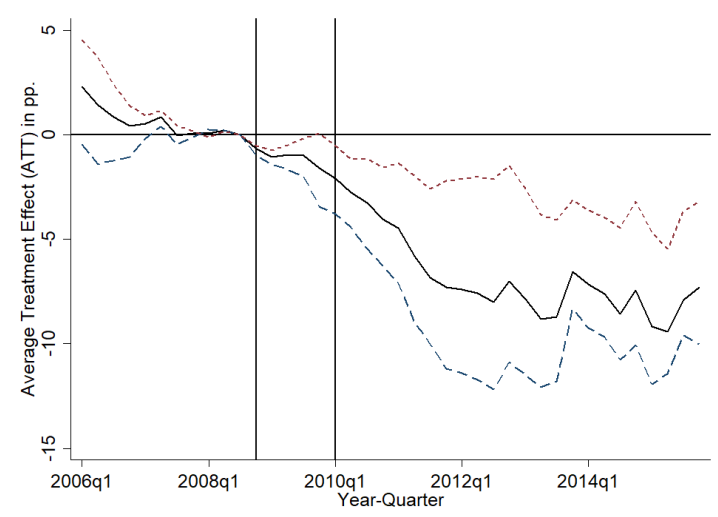

(D) Wages

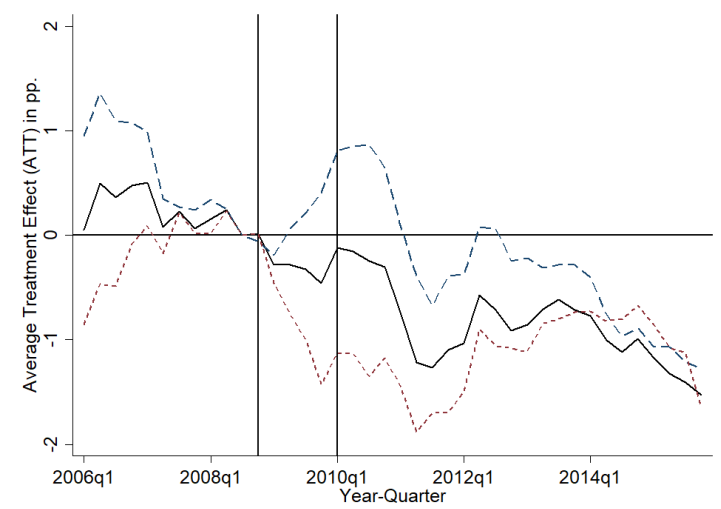

Figure 15. Full Sample, Affected Firms with Rigid Wages, and Affected Firms with Flexible Wages: Comparing Treatment Effect Curves Over Time. This figure compares the average treatment effects on the treated (ATT) on the change in investment (Panel A), the change in the logarithm of property, plant, and equipment (PPE) assets (Panel B), the change in the logarithm of employment (Panel C), and the change in the logarithm of wages (Panel D) between 2008-Q3 (the last quarter before the credit supply shock) and multiple pre- and post periods from 2006-Q1 to 2015-Q4. The solid black line in each panel represent the matching estimates based on the full sample (Figures 7, 8, 11, and 12), the dashed blue line in each panel represents the matching estimates based on treatment firms with rigid wages (Figure 13), and the dotted red line in each panel represents the matching estimates based on treatment firms with flexible wages (Figure 14). Confidence bands are omitted for clarity. The two vertical lines in each panel mark 2008-Q4 and 2010-Q1, the beginning and end of the credit crunch period in my sample. 
(A) Investment

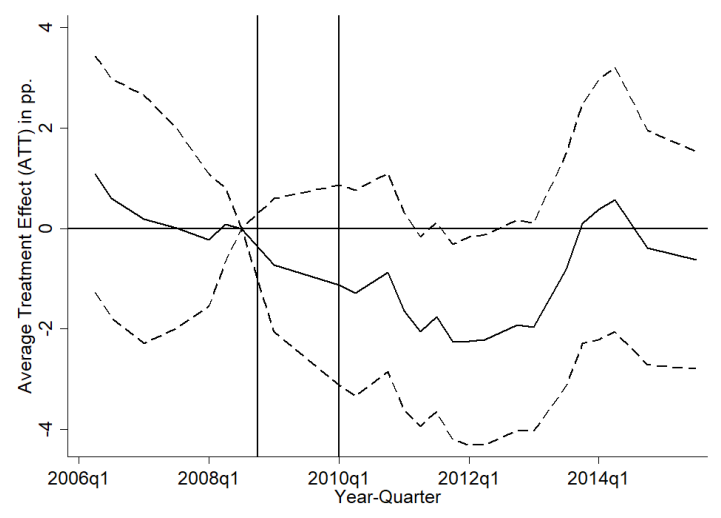

(C) Employment

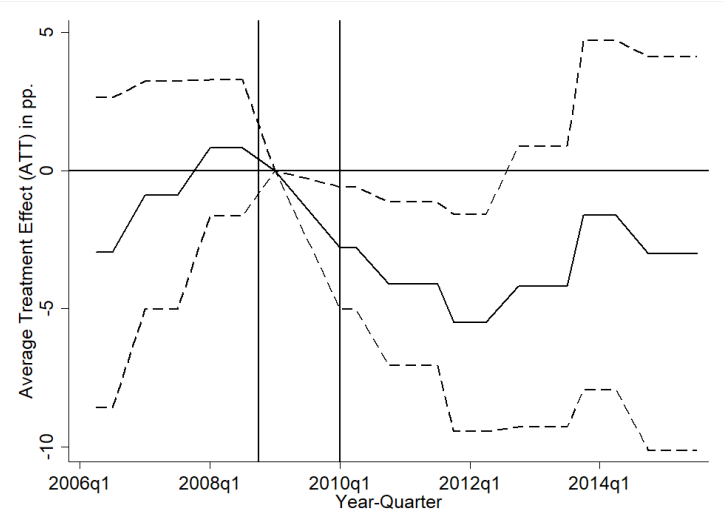

(B) Firm Growth

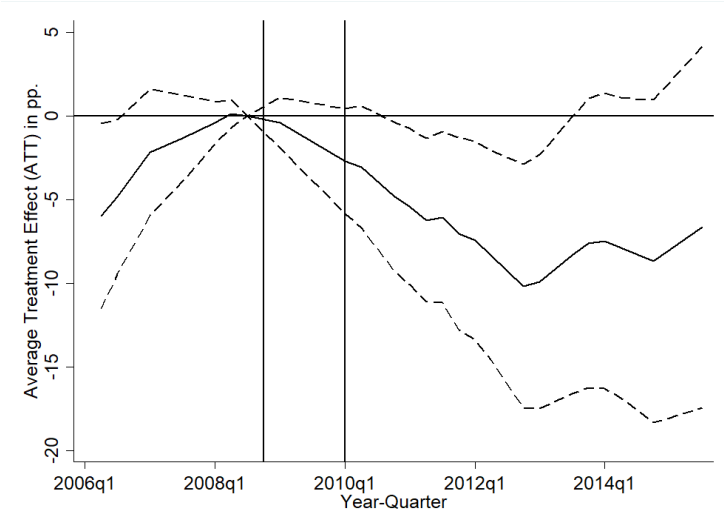

(D) Wages

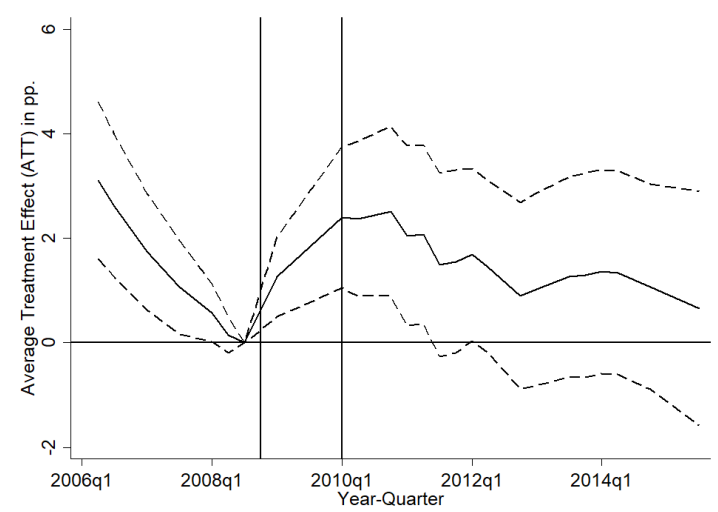

Figure 16. Affected Firms With Rigid Wages versus Affected Firms With Flexible Wages: Treatment Effect Curves Over Time. This figure shows the average treatment effect on the treated (ATT) on the change in investment (Panel A), the change in the logarithm of property, plant, and equipment (PPE) assets (Panel B), the change in the logarithm of employment (Panel C), and the change in the logarithm of wages (Panel D) between 2008-Q3 (the last quarter before the credit supply shock) and multiple pre- and post periods from 2006-Q1 to 2015-Q4. Treated firms are firms which have at least one term loan maturing or credit line expiring during the period from 2008-Q4 to 2010-Q1 and which have a below-median wage share of payroll adjustment. Non-treated firms in the matched control group are firms which have at least one term loan maturing or credit line expiring during the period from 2008-Q4 to 2010-Q1 and which have an above-median wage share of payroll adjustment. The solid line in each panel represents the matching estimates for the ATT based on the results in Table IX. The two dashed lines in each panel represent the 95\% confidence intervals. The two vertical lines in each panel mark 2008-Q4 and 2010-Q1, the beginning and end of the credit crunch period in my sample. 


\section{Appendix B: Tables}

\section{Table I \\ Variable Definitions}

This table shows the definitions of all dependent variables, matching variables, and wage rigidity variables used in the paper. The definitions provide the items of Compustat's North America Fundamentals Quarterly database or the items of the Quarterly Workforce Indicators (QWI) database used to construct the variables.

\begin{tabular}{|c|c|c|}
\hline Variable & Definition & Data Sourc \\
\hline \multicolumn{3}{|l|}{ Dependent Variables } \\
\hline$\Delta$ Investment & Investment $_{t+k}$ - Investment $t$ & Compustat \\
\hline$\Delta$ Log PPE Assets & $\log \left(\right.$ ppent $\left._{t+k}\right)-\log \left(\right.$ ppent $\left._{t}\right)$ & Compustat \\
\hline$\Delta$ Log Employment & $\log \left(e m p_{t+k}\right)-\log \left(e m p_{t}\right)$ & Compustat \\
\hline$\Delta$ Log Wages & $\log \left(\right.$ Wage $\left._{t+k}\right)-\log \left(\right.$ Wage $\left._{t}\right)$ & QWI \\
\hline Log(Wage) & $\frac{\left.\left(\log _{\left(e a r n s_{t}\right.}\right)+\log \left(\text { earns }_{t-1}\right)+\log \left(\text { earns }_{t-2}\right)+\log \left(\text { earns }_{t-3}\right)\right)}{4}$ & QWI \\
\hline \multicolumn{3}{|l|}{ Matching Variables } \\
\hline Size & $\log \left(a t q_{t}\right)$ & Compustat \\
\hline Investment & 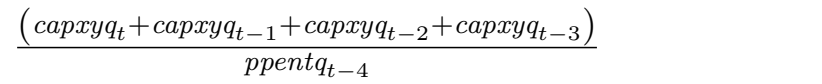 & Compustat \\
\hline Cash Holdings & $\frac{c h e q_{t}}{a t q_{t}}$ & Compustat \\
\hline Q & $\frac{a t q_{t}+p r c c q_{t} \times c s h o q_{t}-c e q q_{t}}{a t q_{t}}$ & Compustat \\
\hline Cash Flow & $\frac{i b q_{t}+d p q_{t}}{p p e n t q_{t-1}}$ & Compustat \\
\hline Return on Assets & $\frac{o i b d p q_{t}}{a t q_{t-1}}$ & Compustat \\
\hline Long-Term Leverage & $\frac{d l t t q_{t}}{a t q_{t}}$ & Compustat \\
\hline SIC Industry Code & sic & Compustat \\
\hline
\end{tabular}

Wage Rigidity Variables

Payroll

$e m p_{t} \times e^{e a r n s} s_{t}$

Compustat/QWI

Wage Rigidity $\theta_{t}$

$\frac{1}{T} \sum_{t=1}^{T} \frac{\Delta \log \left(\text { earns }_{t}\right)}{\Delta \log \left(\text { Payroll }_{t}\right)}$

Compustat/QWI 
Table II

\section{Summary Statistics: Syndicated Loans}

This table reports the summary statistics of 1,281 treatment facilities and 6,018 non-treatment facilities at the individual loan level. A treatment facility is a term loan maturing or credit line expiring between 2008-Q4 and 2010-Q1, and a non-treatment facility is a term loan maturing or credit line expiring either before 2008-Q4 or after 2010-Q1. The table reports the means, standard deviations (SD), as well as the $10^{t h}, 50^{t h}$, and $90^{t h}$ percentiles of the distributions of the respective sample of loan facilities. The variable Term Loan Indicator takes on the value of 1 if the facility is a term loan and 0 if the facility is a credit line. The variable Credit Line Indicator vice versa takes on the value of 1 if the facility is a credit line and 0 if the facility is a term loan. For definitions of term loans and credit lines, I follow Berg, Saunders, and Steffen (2016).

\begin{tabular}{|c|c|c|c|c|c|c|c|c|c|c|c|}
\hline & \multicolumn{5}{|c|}{ Treatment Facilities } & \multicolumn{6}{|c|}{ Non-Treatment Facilities } \\
\hline & $\#$ & Mean SD & 10th & 50 th & 90 th & $\#$ & Mea & $n \mathrm{SD}$ & 10th & 50 th & 90 th \\
\hline Facility Volume $(\$ M)$ & 1281 & $481 \quad 1173$ & 25 & 200 & 1500 & 6018 & 581 & 1019 & 40 & 291 & 1468 \\
\hline Maturity (Months) & 1281 & 24 & 12 & 60 & 70 & 6018 & 59 & 23 & 36 & 60 & 83 \\
\hline Term Loan Indicator & & $0.35 \quad 0.48$ & & & & & 0.34 & 0.47 & & & \\
\hline Credit Line Indicator & & $0.65 \quad 0.48$ & & & & & 0.66 & 0.47 & & & \\
\hline
\end{tabular}




\section{Table III \\ Matching Quality}

This table provides pre-treatment summary statistics on treated firms, non-treated firms, and matched control firms. Panel A compares the mean values of firm characteristics of 736 treated and 1013 non-treated firms in the unmatched sample. Treated firms are firms which have at least one term loan maturing or credit line expiring during the period from 2008-Q4 and 2010-Q1, while non-treated firms have neither a term loan maturing nor credit line expiring during this period. The table provides two different measures for the balancedness of the sample: \%Bias is the difference of the sample means between treated and non-treated firms as a percentage of the square root of the average of sample variances in both groups; t-stat is the test statistic of the two-sample t-test for differences in means. Panel B compares the mean values of firm characteristics of treated firms and the sample of matched control firms based on the Abadie and Imbens (2006) matching estimator. $*$, **, and $* * *$ indicate statistical significance at the $10 \%, 5 \%$, and $1 \%$ level respectively. The definitions of all matching covariates are presented in Table I.

\begin{tabular}{|c|c|c|c|c|}
\hline Matching Covariate & Treated & Non-Treated & $\%$ Bias & t-Stat \\
\hline Size & 21.62 & 20.11 & 81.83 & $16.69^{* *}$ \\
\hline Investment & 5.79 & 7.27 & -27.40 & $-5.48^{* *}$ \\
\hline Cash Holdings & 7.88 & 15.09 & -50.07 & $-9.96^{* *}$ \\
\hline Q & 1.53 & 1.70 & -17.41 & $-3.37^{* *}$ \\
\hline Cash Flow & 8.04 & 7.94 & 0.18 & 0.04 \\
\hline Return on Assets & 3.39 & 2.52 & 22.58 & $4.38^{* *}$ \\
\hline Long-Term Leverage & 26.64 & 19.27 & 34.31 & $7.01^{* *}$ \\
\hline Number of Firms & 736 & 1013 & & \\
\hline \multicolumn{5}{|c|}{ Panel B: Treated and Control Firms (Matched Sample) } \\
\hline Matching Covariate & Treated & Control & $\%$ Bias & t-Stat \\
\hline Size & 21.62 & 21.64 & -1.54 & -0.28 \\
\hline Investment & 5.79 & 5.49 & 7.78 & 1.43 \\
\hline Cash Holdings & 7.88 & 7.72 & 1.67 & 0.31 \\
\hline $\mathrm{Q}$ & 1.53 & 1.48 & 7.55 & 1.33 \\
\hline Cash Flow & 8.04 & 9.18 & -2.74 & -0.49 \\
\hline Return on Assets & 3.39 & 3.49 & -3.96 & -0.72 \\
\hline Long-Term Leverage & 26.64 & 25.68 & 5.15 & -0.72 \\
\hline Number of Firms & 736 & 736 & & \\
\hline
\end{tabular}




\section{Table IV \\ Matching Results: Investment and Firm Growth}

This table reports the difference-in-differences matching estimation results for the average treatment effect on the treated (ATT) on investment and firm growth based on the bias-corrected Abadie and Imbens (2006) matching estimator. Treated firms are firms which have at least one term loan maturing or credit line expiring during the period from 2008-Q4 and 2010-Q1, while non-treated firms have neither a term loan maturing nor credit line expiring during this period. To each treated firm, I match one control firm from the control group pool of non-treated firms to produce a balanced sample in terms of firm size, investment ratio, cash holdings, Q, cash flow, return on assets, and long-term leverage. Additionally I match on the 1-digit SIC industry code. The first two columns present the estimates and standard errors for the change in the investment ratio, and the next two columns present the estimates and standard errors for the change in the logarithm of property, plant, and equipment (PPE) assets. Each row contains the change between the period before the credit supply shock (2008-Q3) and the respective post-period. *, **, and *** indicate statistical significance at the $10 \%, 5 \%$, and $1 \%$ level respectively.

Dependent Variable

(1)

Post Period

2010-Q2

2010-Q3

2010-Q4

2011-Q1

2011-Q2

2011-Q3

2011-Q4

2012-Q1

2012-Q2

2012-Q3

2012-Q4

2013-Q1

2013-Q2

2013-Q3

2013-Q4

2014-Q1

2014-Q2

2014-Q3

2014-Q4

2015-Q1

2015-Q2

2015-Q3

2015-Q4

Observations
$\Delta$ Investment

(2)

S.E.

0.7

0.7

0.8

0.8

0.9

0.8

0.9

0.9

0.9

0.9

0.9

0.9

0.9

0.9

0.9

0.9

0.9

0.9

0.9

0.9

0.8

0.8

$\begin{array}{ll}-0.4 & 0.8 \\ -0.4 & 0.8\end{array}$
$\Delta$ Log PPE Assets

(3)

ATT

S.E.

$-2.9^{* *} \quad 1.5$

$-3.6^{* *} \quad 1.6$

$-4.1^{* *} \quad 1.8$

$-4.6^{* *} \quad 2.0$

$-6.3^{* * *} \quad 2.1$

$-7.2^{* * *} \quad 2.3$

$-7.9^{* * *} \quad 2.5$

$-8.1^{* * *} \quad 2.6$

$-7.9^{* * *} \quad 2.7$

$-8.1^{* * *} \quad 2.8$

$-7.5^{* *} \quad 3.0$

$-8.6^{* * *} \quad 3.1$

$-9.5^{\text {*** }} \quad 3.3$

$-9.4^{* * *} \quad 3.3$

$-7.8^{* *} \quad 3.5$

$-8.4^{* *} \quad 3.6$

$-9.0^{* *} \quad 3.7$

$-9.6^{* *} \quad 3.7$

$-8.7^{* *} \quad 3.9$

$-9.6^{* *} \quad 3.9$

$-9.8^{* *} \quad 4.0$

$\begin{array}{ll}-8.0 * & 4.1\end{array}$

$-8.7^{* *} \quad 4.4$

736 


\section{Table V \\ Matching Results: Employment and Wage Growth}

This table reports the difference-in-differences matching estimation results for the average treatment effect on the treated (ATT) on employment and wage growth based on the bias-corrected Abadie and Imbens (2006) matching estimator. Treated firms are firms which have at least one term loan maturing or credit line expiring during the period from 2008-Q4 and 2010-Q1, while nontreated firms have neither a term loan maturing nor credit line expiring during this period. To each treated firm, I match one control firm from the control group pool of non-treated firms to produce a balanced sample in terms of firm size, investment ratio, cash holdings, Q, cash flow, return on assets, and long-term leverage. Additionally I match on the 1-digit SIC industry code. The first two columns present the estimates and standard errors for the change in the logarithm of employment, and the next two columns present the estimates and standard errors for the change in the logarithm of wages. Each row contains the change between the period before the credit supply shock $(2008-\mathrm{Q} 3)$ and the respective post-period. $*{ }^{* *}$, and $* * *$ indicate statistical significance at the $10 \%, 5 \%$, and $1 \%$ level respectively.

Dependent Variable

Post Period

2010-Q2

2010-Q3

2010-Q4

2011-Q1

2011-Q2

2011-Q3

2011-Q4

2012-Q1

2012-Q2

2012-Q3

2012-Q4

2013-Q1

2013-Q2

2013-Q3

2013-Q4

2014-Q1

2014-Q2

2014-Q3

2014-Q4

2015-Q1

2015-Q2

2015-Q3

2015-Q4

Observations
(1)

$\Delta$ Log Employment

(2)

ATT

$-0.2$

$-0.2$

$-0.7$

$-0.7$

$-0.7$

$-0.7$

$-2.2$

$-2.2$

$-2.2$

$-2.2$

$-2.1$

$-2.1$

$-2.1$

$-2.1$

$-0.2$

$-0.2$

$-0.2$

$-0.2$

$-1.1$

$-1.1$

$-1.1$

$-1.1$

0.7

736
$\Delta$ Log Wages

(3)

(4)

ATT

S.E.

$-0.1$

0.6

$-0.2$

0.6

$-0.2$

0.6

$-0.7$

0.6

$-1.1$

0.6

$-1.2$

0.7

$-1.0$

0.6

$-1.0$

0.6

$-0.5$

0.6

$-0.7$

0.7

$-0.9$

0.7

$-0.9$

0.7

$-0.7$

0.7

$-0.6$

0.7

$-0.7$

0.8

$-0.7$

$-1.0$

0.8

0.8

$-1.1$

0.8

$-1.0$

0.8

$-1.3$

0.8

$-1.4$

0.8

$-1.5$

0.9

$-1.6$

0.9 


\section{Table VI \\ Sample Split Matching Results: Investment and Firm Growth}

This table reports the difference-in-differences matching estimation results for the average treatment effect on the treated (ATT) on investment and firm growth separately for treated firms with rigid wages and treated firms with flexible wages. Treated firms with rigid (flexible) wages are firms which have at least one term loan maturing or credit line expiring during the period from 2008-Q4 and 2010-Q1 and which have a below (above) median wage share of payroll adjustment. Nontreated firms in the control group pool have neither a term loan maturing nor credit line expiring from 2008-Q4 and 2010-Q1. To each treated firm, I match one control firm from the control group pool of non-treated firms to produce a balanced sample in terms of firm size, investment ratio, cash holdings, Q, cash flow, return on assets, and long-term leverage. Additionally, I match on the 1-digit SIC industry code. Column 1 and 2 present the estimates for the change in investment and Column 3 and 4 present the estimates for the change in the logarithm of property, plant, and equipment (PPE) assets. Each row contains the change between the period before the credit supply shock (2008-Q3) and the respective post-period. *, **, and $* * *$ indicate statistical significance at the $10 \%, 5 \%$, and $1 \%$ level respectively. Standard errors are omitted for brevity.

\begin{tabular}{|c|c|c|c|c|}
\hline Dependent Variable & \multicolumn{2}{|c|}{$\Delta$ Investment } & \multicolumn{2}{|c|}{$\Delta$ Log PPE Assets } \\
\hline & $(1)$ & $(2)$ & $(3)$ & $(4)$ \\
\hline Post Period & ATT Rigid & ATT Flexible & ATT Rigid & ATT Flexible \\
\hline 2010-Q2 & $-1.6 *$ & 0.0 & $-4.4^{* *}$ & -1.2 \\
\hline 2010-Q3 & $-1.9^{* *}$ & -0.2 & $-5.4^{* * *}$ & -1.2 \\
\hline 2010-Q4 & $-1.9 *$ & -0.5 & $-6.3^{* *}$ & -1.6 \\
\hline 2011-Q1 & $-2.0^{*}$ & -0.1 & $-7.1^{* * *}$ & -1.4 \\
\hline 2011-Q2 & $-2.5^{* *}$ & 0.5 & $-8.9^{* * *}$ & -2.0 \\
\hline 2011-Q3 & $-2.3^{* *}$ & 0.3 & $-10.0^{* * *}$ & -2.6 \\
\hline 2011-Q4 & $-2.0^{*}$ & 0.3 & $-11.2^{* * *}$ & -2.2 \\
\hline 2012-Q1 & $-2.1^{*}$ & 0.1 & $-11.4^{* * *}$ & -2.1 \\
\hline 2012-Q2 & -0.9 & -0.5 & $-11.7^{* * *}$ & -2.0 \\
\hline 2012-Q3 & -1.1 & -0.7 & $-12.2^{* * *}$ & -2.1 \\
\hline 2012-Q4 & -0.5 & -0.6 & $-10.9^{* * *}$ & -1.5 \\
\hline 2013-Q1 & -0.6 & -0.8 & $-11.5^{* * *}$ & -2.6 \\
\hline 2013-Q2 & -0.5 & -0.6 & $-12.1^{* * *}$ & -3.8 \\
\hline 2013-Q3 & 0.2 & -0.6 & $-11.8^{* * *}$ & -4.1 \\
\hline 2013-Q4 & 0.3 & -1.4 & $-8.3 *$ & -3.1 \\
\hline 2014-Q1 & 0.5 & -1.3 & $-9.3 *$ & -3.6 \\
\hline 2014-Q2 & 0.7 & -0.7 & $-9.7^{*}$ & -4.0 \\
\hline 2014-Q3 & 0.2 & -0.7 & $-10.8^{* *}$ & -4.4 \\
\hline 2014-Q4 & -0.7 & -0.7 & $-10.1 *$ & -3.2 \\
\hline 2015-Q1 & -0.6 & -0.5 & $-11.9^{* *}$ & -4.7 \\
\hline 2015-Q2 & -0.3 & -0.3 & $-11.4^{* *}$ & -5.5 \\
\hline 2015-Q3 & -0.2 & -0.2 & $-9.6 *$ & -3.6 \\
\hline 2015-Q4 & -0.5 & -0.1 & -10.0 & -3.2 \\
\hline Observations & 334 & & 334 & \\
\hline
\end{tabular}




\section{Table VII}

\section{Sample Split Matching Results: Employment and Wage Growth}

This table reports the difference-in-differences matching estimation results for the average treatment effect on the treated (ATT) on employment and wage growth separately for treated firms with rigid wages and treated firms with flexible wages. Treated firms with rigid (flexible) wages are firms which have at least one term loan maturing or credit line expiring during the period from 2008-Q4 and 2010-Q1 and which have a below (above) median wage share of payroll adjustment. Non-treated firms in the control group pool have neither a term loan maturing nor credit line expiring from 2008-Q4 and 2010-Q1. To each treated firm, I match one control firm from the control group pool of non-treated firms to produce a balanced sample in terms of firm size, investment ratio, cash holdings, Q, cash flow, return on assets, and long-term leverage. Additionally, I match on the 1-digit SIC industry code. Column 1 and 2 present the estimates for the change in investment and Column 3 and 4 present the estimates for the change in the logarithm of property, plant, and equipment (PPE) assets. Each row contains the change between the period before the credit supply shock $(2008-\mathrm{Q} 3)$ and the respective post-period. ${ }^{*}, * *$, and $* * *$ indicate statistical significance at the $10 \%, 5 \%$, and $1 \%$ level respectively. Standard errors are omitted for brevity.

\begin{tabular}{|c|c|c|c|c|}
\hline \multirow[t]{2}{*}{ Dependent Variable } & \multicolumn{2}{|c|}{$\Delta$ Log Employment } & \multicolumn{2}{|c|}{$\Delta$ Log Wages } \\
\hline & (1) & $(2)$ & $(3)$ & $(4)$ \\
\hline Post Period & ATT Rigid & ATT Flexible & ATT Rigid & ATT Flexible \\
\hline 2010-Q2 & $-2.3^{*}$ & 1.7 & 0.9 & -1.1 \\
\hline 2010-Q3 & $-2.3 *$ & 1.7 & 0.9 & $-1.4^{*}$ \\
\hline 2010-Q4 & -2.3 & 1.8 & 0.6 & -1.2 \\
\hline 2011-Q1 & -2.3 & 1.8 & 0.1 & $-1.4^{*}$ \\
\hline 2011-Q2 & -2.3 & 1.8 & -0.4 & $-1.9^{* *}$ \\
\hline 2011-Q3 & -2.3 & 1.8 & -0.7 & $-1.7^{*}$ \\
\hline 2011-Q4 & -3.6 & 1.2 & -0.4 & $-1.7 *$ \\
\hline 2012-Q1 & -3.6 & 1.2 & -0.4 & $-1.5^{*}$ \\
\hline 2012-Q2 & -3.6 & 1.2 & 0.1 & -0.9 \\
\hline 2012-Q3 & -3.6 & 1.2 & 0.1 & -1.1 \\
\hline 2012-Q4 & -2.9 & 0.9 & -0.2 & -1.1 \\
\hline 2013-Q1 & -2.9 & 0.9 & -0.2 & -1.1 \\
\hline 2013-Q2 & -2.9 & 0.9 & -0.3 & -0.8 \\
\hline 2013-Q3 & -2.9 & 0.9 & -0.3 & -0.8 \\
\hline 2013-Q4 & 0.4 & 3.1 & -0.3 & -0.7 \\
\hline 2014-Q1 & 0.4 & 3.1 & -0.4 & -0.7 \\
\hline 2014-Q2 & 0.4 & 3.1 & -0.8 & -0.8 \\
\hline 2014-Q3 & 0.4 & 3.1 & -1.0 & -0.8 \\
\hline 2014-Q4 & -0.4 & 2.4 & -0.9 & -0.7 \\
\hline 2015-Q1 & -0.4 & 2.4 & -1.1 & -0.9 \\
\hline 2015-Q2 & -0.4 & 2.4 & -1.1 & -1.1 \\
\hline 2015-Q3 & -0.4 & 2.4 & -1.2 & -1.1 \\
\hline 2015-Q4 & 0.3 & 3.6 & -1.3 & -1.6 \\
\hline Observations & 334 & & 334 & \\
\hline
\end{tabular}




\section{Table VIII}

\section{Matching Quality: Affected Firms with Rigid and Flexible Wages}

This table provides pre-treatment summary statistics on treated firms with rigid wages, treated firms with flexible wages, and treated firms with flexible wages in the matched control group. Panel A compares the mean values of firm characteristics of 334 treated firms with rigid wages and 334 treated firms with flexible wages in the unmatched sample. Treated firms with rigid (flexible) wages are firms which have at least one term loan maturing or credit line expiring during the period from 2008-Q4 and 2010-Q1 and which have a below (above) median wage share of payroll adjustment. The table provides two different measures for the balancedness of the sample: \%Bias is the difference of the sample means between treated and non-treated firms as a percentage of the square root of the average of sample variances in both groups; t-stat is the test statistic of q twosample t-test for differences in means. Panel B compares the mean values of firm characteristics of treated firms with rigid wages and the sample of matched control treated firms with flexible wages based on the Abadie and Imbens (2006) matching estimator. *, **, and *** indicate statistical significance at the $10 \%, 5 \%$, and $1 \%$ level respectively. The definitions of all matching covariates are presented in Table I.

\begin{tabular}{|c|c|c|c|c|}
\hline Matching Covariate & Rigid & Flexible & $\%$ Bias & t-Stat \\
\hline Size & 21.39 & 21.99 & -37.95 & $-4.87^{* * *}$ \\
\hline Investment & 6.27 & 5.20 & 25.49 & $3.25^{* * *}$ \\
\hline Cash Holdings & 8.28 & 7.21 & 10.85 & 1.39 \\
\hline Q & 1.52 & 1.55 & -4.72 & -0.58 \\
\hline Cash Flow & -2.17 & 10.31 & -24.37 & $-2.32^{* *}$ \\
\hline Return on Assets & 3.21 & 3.58 & -13.57 & $-1.69^{*}$ \\
\hline Long-Term Leverage & 28.35 & 25.31 & 15.84 & $2.03^{* *}$ \\
\hline Number of Firms & 334 & 334 & & \\
\hline
\end{tabular}

\section{Panel B: Affected Firms with Rigid and Flexible Wages (Matched Sample)}

$\begin{array}{lrrrr}\text { Matching Covariate } & \text { Rigid } & \text { Flexible } & \text { \%Bias } & \text { t-Stat } \\ \text { Size } & & & & -1.61 \\ \text { Investment } & 6.27 & 21.59 & -12.47 & 1.93^{*} \\ \text { Cash Holdings } & 8.28 & 8.65 & 14.99 & -0.14 \\ \text { Q } & 1.52 & 1.52 & -1.10 & 0.00 \\ \text { Cash Flow } & -2.17 & 1.49 & -4.34 & -0.55 \\ \text { Return on Assets } & 3.21 & 3.78 & -20.16 & -2.55^{* *} \\ \text { Long-Term Leverage } & 28.35 & 24.31 & 18.76 & 2.42^{* *} \\ \text { Number of Firms } & 334 & 334 & & \end{array}$


Table IX

\section{Matching Results: Affected Firms with Rigid and Flexible Wages}

This table reports the difference-in-differences matching estimation results for the average treatment effect on the treated (ATT) on investment, firm growth, employment growth, and wage growth based on the Abadie and Imbens (2006) matching estimator. Treated firms with rigid (flexible) wages are firms which have at least one term loan maturing or credit line expiring during the period from 2008-Q4 and 2010-Q1 and which have a below (above) median wage share of payroll adjustment. To each treated firm with rigid wages, I match one firm from the control group pool of treated firms with flexible wages to produce a balanced sample in terms of firm size, investment ratio, cash holdings, Q, cash flow, return on assets, and long-term leverage. Additionally I match on the 1-digit SIC industry code. Each row contains the change between the period before the credit supply shock (2008-Q3) and the respective post-period. *, **, and *** indicate statistical significance at the 10\%, 5\%, and 1\% level respectively. Standard errors are omitted for brevity.

Dependent Variable $\Delta$ Investment $\Delta$ Log PPE Assets $\Delta$ Log Employment $\Delta$ Log Wages

Post Period

$\begin{array}{lc}2010-Q 2 & -1.3 \\ 2010-Q 3 & -1.3 \\ 2010-Q 4 & -0.9 \\ 2011-Q 1 & -1.6 \\ 2011-Q 2 & -2.0^{* *} \\ 2011-Q 3 & -1.8^{*} \\ 2011-Q 4 & -2.3^{* *} \\ 2012-Q 1 & -2.2^{* *} \\ 2012-Q 2 & -2.2^{* *} \\ 2012-Q 3 & -2.3{ }^{* *} \\ 2012-Q 4 & -1.9 \\ 2013-Q 1 & -1.7 \\ 2013-Q 2 & -1.1 \\ 2013-Q 3 & -0.8 \\ 2013-Q 4 & 0.1 \\ 2014-Q 1 & 0.4 \\ 2014-Q 2 & 0.6 \\ 2014-Q 3 & 0.2 \\ 2014-Q 4 & -0.4 \\ 2015-Q 1 & -0.6 \\ 2015-Q 2 & -0.7 \\ 2015-Q 3 & -0.6 \\ 2015-Q 4 & 0.1 \\ & \end{array}$

Observations
$-3.0$

$-4.2^{* *}$

$-4.8^{* *}$

$-5.4^{* *}$

$-6.2^{* *}$

$-6.1^{* *}$

$-7.0^{* *}$

$-7.4^{* *}$

$-8.3^{* * *}$

$-8.4^{* *}$

$-10.2^{* * *}$

$-9.9^{* *}$

$-9.8^{* *}$

$-8.3^{* *}$

$-7.6^{*}$

$-7.5^{*}$

-7.9 *

$-8.3^{*}$

$-8.7 *$

-9.1 *

$-7.8$

$-6.7$

$-7.1$

334
$(3)$

(4)

$\begin{array}{ll}-2.8^{* *} & 2.4^{* * *} \\ -2.8^{* *} & 2.7^{* * *} \\ -4.1^{* * *} & 2.5^{* * *} \\ -4.1^{* * *} & 2.1^{* *} \\ -4.1^{* * *} & 2.1^{* *} \\ -4.1^{* * *} & 1.5^{*} \\ -5.5^{* * *} & 1.6^{*} \\ -5.5^{* * *} & 1.7^{* *} \\ -5.5^{* * *} & 1.5{ }^{*} \\ -5.5^{* * *} & 1.1 \\ -4.2^{*} & 0.9 \\ -4.2 & 1.0 \\ -4.2 & 1.0 \\ -4.2 & 1.3 \\ -1.6 & 1.3 \\ -1.6 & 1.4 \\ -1.6 & 1.3 \\ -1.6 & 1.2 \\ -3.0 & 1.1 \\ -3.0 & 0.8 \\ -3.0 & 0.9 \\ -3.0 & 0.7 \\ -2.7 & 0.9\end{array}$

334

334 


\section{Table X}

\section{Robustness Check: Alternative Definition of the Treatment Period}

This table reports the difference-in-differences matching estimation results for the average treatment effect on the treated (ATT) on investment, firm, employment, and wage growth using an alternative definition for the treatment period. Treated firms are firms which have at least one term loan maturing or credit line expiring during the period from 2009-Q1 and 2009-Q4. Non-treated firms in the matched control have neither a term loan maturing nor credit line expiring during this period. To each treated firm, I match one control firm from the control group pool of non-treated firms to produce a balanced sample in terms of firm size, investment ratio, cash holdings, Q, cash flow, return on assets, and long-term leverage. Additionally I match on the 1-digit SIC industry code. Each row contains the change between the period before the credit supply shock (2008-Q3) and the respective post-period. ${ }^{*}, * *$, and ${ }^{* * *}$ indicate statistical significance at the $10 \%, 5 \%$, and $1 \%$ level respectively. Standard errors are omitted for brevity.

Dependent Variable $\Delta$ Investment $\Delta$ Log PPE Assets $\Delta$ Log Employment $\Delta$ Log Wages

Post Period

$\begin{array}{ll}2010-Q 2 & -0.9^{* *} \\ 2010-Q 3 & -1.5^{* *} \\ 2010-Q 4 & -1.7^{* *} \\ 2011-Q 1 & -1.7^{* *} \\ 2011-Q 2 & -2.0^{* *} \\ 2011-Q 3 & -2.0^{* *} \\ 2011-Q 4 & -1.9^{* *} \\ 2012-Q 1 & -1.9^{* *} \\ 2012-Q 2 & -1.4^{*} \\ 2012-Q 3 & -1.2 \\ 2012-Q 4 & -0.6 \\ 2013-Q 1 & -0.7 \\ 2013-Q 2 & -0.6 \\ 2013-Q 3 & -0.5 \\ 2013-Q 4 & -0.7 \\ 2014-Q 1 & -0.6 \\ 2014-Q 2 & -0.4 \\ 2014-Q 3 & -0.5 \\ 2014-Q 4 & -0.9 \\ 2015-Q 1 & -1.0 \\ 2015-Q 2 & -0.4 \\ 2015-Q 3 & -0.2 \\ 2015-Q 4 & -0.1\end{array}$

$$
\begin{aligned}
-3.4^{* *} \\
-4.1^{* *} \\
-5.1^{* * *} \\
-5.1^{* *} \\
-6.8^{* * *} \\
-7.5^{* * *} \\
-8.9^{* * *} \\
-8.9^{* * *} \\
-8.9^{* * *} \\
-9.0^{* * *} \\
-9.0^{* * *} \\
-9.8^{* * *} \\
-11.0^{* * *} \\
-11.1^{* * *} \\
-9.1^{* * *} \\
-9.7^{* * *} \\
-10.0^{* * *} \\
-11.3^{* * *} \\
-10.5^{* * *} \\
-12.3^{* * *} \\
-12.3^{* * *} \\
-11.5^{* * *} \\
-11.5^{* * *}
\end{aligned}
$$

581

581
$-0.3$

$-0.4$

$-0.3$

$-0.4$

$-0.7$

$-0.6$

$-0.7$

$-0.7$

$-0.7$

$-2.7$

$-2.7$

$-2.7$

$-2.7$

$-3.0$

$-3.0$

$-3.0$

$-3.0$

$-1.0$

$-1.0$

$-1.0$

$-1.0$

$-1.3$

$-1.3$

$-0.9$

$-1.3^{* *}$

$-1.3^{* *}$

$-1.0$

$-1.1^{*}$

$-0.8$

$-0.8$

$-1.0$

$-0.7$

$-0.5$

$-0.3$

$-0.2$

$-0.3$

$-0.6$

$-0.7$

$-0.8$

$-0.9$

$-1.1$

$-1.3$

$-1.2$

$-1.3$

$-1.4$

Observations

581

581 


\section{Table XI}

\section{Robustness Check: Alternative Definition of the Treatment Group}

This table reports the difference-in-differences matching estimation results for the average treatment effect on the treated (ATT) on investment, firm, employment, and wage growth using an alternative definition for the treatment group. Treated firms are firms which have at least one term loan maturing or credit line expiring during the period from 2008-Q4 and 2010-Q1 and for which the volume of the maturing term loans or expiring credit lines is more than 5\% (10\%) of total assets. Non-treated firms in the matched control group have neither a term loan maturing nor credit line expiring during this period. To each treated firm, I match one control firm from the control group pool of non-treated firms to produce a balanced sample in terms of firm size, investment ratio, cash holdings, Q, cash flow, return on assets, and long-term leverage. Additionally I match on the 1digit SIC industry code. Each row contains the change between the period before the credit supply shock (2008-Q3) and the respective post-period. *, **, and *** indicate statistical significance at the $10 \%, 5 \%$, and $1 \%$ level respectively. Standard errors are omitted for brevity.

\begin{tabular}{|c|c|c|c|c|c|c|c|c|}
\hline \multirow{2}{*}{$\begin{array}{l}\text { Dep. Var. } \\
\text { Post Period }\end{array}$} & \multicolumn{2}{|c|}{$\Delta$ Investment } & \multicolumn{2}{|c|}{$\Delta$ Log PPE Assets } & \multicolumn{2}{|c|}{$\Delta$ Log Employment } & \multicolumn{2}{|c|}{$\Delta$ Log Wages } \\
\hline & (1) & $(2)$ & $(3)$ & $(4)$ & $(5)$ & (6) & (7) & $(8)$ \\
\hline & $>5 \%$ & $>10 \%$ & $>5 \%$ & $>10 \%$ & $>5 \%$ & $>10 \%$ & $>5 \%$ & $>10 \%$ \\
\hline 2010-Q2 & $-1.3^{*}$ & $-1.7^{* *}$ & $-2.8^{*}$ & $-3.6^{* *}$ & -0.5 & -1.2 & 0.3 & 0.7 \\
\hline 2010-Q3 & $-1.6^{* *}$ & $*-2.0^{* *}$ & $-3.5^{* *}$ & $-4.5^{* *}$ & -0.5 & -1.2 & 0.3 & 0.6 \\
\hline 2010-Q4 & $-1.7^{* *}$ & $*-2.1^{* *}$ & $-4.3^{* *}$ & $-5.4^{* *}$ & -1.2 & -2.3 & 0.1 & 0.3 \\
\hline 2011-Q1 & $-1.4^{*}$ & $-1.6^{*}$ & $-4.3^{* *}$ & $-5.1^{* *}$ & -1.2 & -2.3 & -0.3 & -0.2 \\
\hline 2011-Q2 & $-1.7 *$ & $-2.2^{* *}$ & $-5.8^{* * *}$ & $-6.4^{* * *}$ & -1.2 & -2.3 & -0.8 & -0.6 \\
\hline 2011-Q3 & $-1.7 *$ & $-2.1^{* *}$ & $-7.2^{* * *}$ & $-7.9^{* * *}$ & -1.2 & -2.3 & -0.8 & -0.7 \\
\hline 2011-Q4 & $-1.8^{* *}$ & $*-2.1^{* *}$ & $-8.3^{* * *}$ & $-8.9^{* * *}$ & -2.5 & -3.6 & -0.5 & -0.3 \\
\hline 2012-Q1 & $-2.0^{* *}$ & $*-2.3^{* *}$ & $-8.5^{* * *}$ & $-9.0^{* * *}$ & -2.5 & -3.6 & -0.5 & -0.5 \\
\hline 2012-Q2 & $-1.7 *$ & $-1.8 *$ & $-8.5^{* * *}$ & $-9.4^{* * *}$ & -2.5 & -3.6 & -0.1 & 0.1 \\
\hline 2012-Q3 & $-1.7 *$ & $-1.8 *$ & $-8.8^{* * *}$ & $-10.3^{* * *}$ & -2.5 & -4.6 & -0.3 & 0.0 \\
\hline 2012-Q4 & -1.0 & -1.1 & $-8.2^{* *}$ & $-10.3^{* * *}$ & -2.9 & $-4.9 *$ & -0.7 & -0.3 \\
\hline 2013-Q1 & -1.0 & -1.3 & $-9.3^{* * *}$ & $-11.8^{* * *}$ & -2.9 & $-4.9 *$ & -0.5 & -0.3 \\
\hline 2013-Q2 & -0.6 & -0.8 & $-10.1^{* * *}$ & $-12.4^{* * *}$ & -2.9 & $-4.9^{*}$ & -0.5 & -0.3 \\
\hline 2013-Q3 & 0.1 & -0.1 & $-9.9^{* * *}$ & $-12.1^{* * *}$ & -2.9 & $-4.9 *$ & -0.5 & -0.3 \\
\hline 2013-Q4 & -0.2 & -0.2 & $-7.4^{* *}$ & $-8.8^{* *}$ & -1.5 & -4.4 & -0.4 & -0.3 \\
\hline 2014-Q1 & 0.2 & 0.3 & $-8.0^{* *}$ & $-9.5^{* *}$ & -1.5 & -4.4 & -0.5 & -0.3 \\
\hline 2014-Q2 & 0.7 & 1.0 & $-8.8^{* *}$ & $-10.7^{* *}$ & -1.5 & -4.4 & -0.8 & -0.6 \\
\hline 2014-Q3 & 0.5 & 0.8 & $-9.8^{* *}$ & $-11.8^{* * *}$ & -1.5 & -5.4 & -0.9 & -0.6 \\
\hline 2014-Q4 & -0.2 & 0.1 & $-9.2^{* *}$ & $-10.7^{* *}$ & -2.2 & -5.6 & -0.8 & -0.5 \\
\hline 2015-Q1 & -0.3 & -0.1 & $-10.6^{* *}$ & $-12.1^{* * *}$ & -2.2 & -5.6 & -1.3 & -0.8 \\
\hline 2015-Q2 & 0.0 & 0.4 & $-10.6^{* *}$ & $-12.2^{* *}$ & -2.2 & -5.6 & $-1.4 *$ & -1.0 \\
\hline 2015-Q3 & -0.1 & 0.2 & $-8.9^{* *}$ & $-11.2^{* *}$ & -2.2 & -5.6 & $-1.5 *$ & -1.4 \\
\hline 2015-Q4 & -0.1 & -0.1 & $-9.9^{* *}$ & $-11.9^{* *}$ & -1.2 & -5.5 & $-1.9^{* *}$ & $-2.0^{* *}$ \\
\hline Observations & 595 & 430 & 595 & 430 & 595 & 430 & 595 & 430 \\
\hline
\end{tabular}




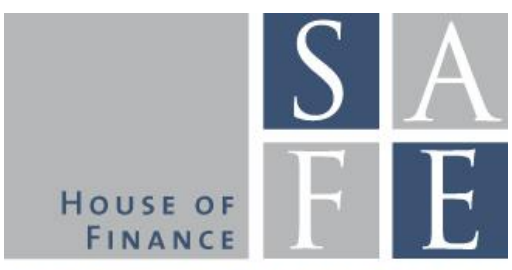

WORKING PAPER SERIES

\section{Recent Issues}

No. 188 Michael Donadelli, Patrick Grüning, Marcus Jüppner, Renatas Kizys

No. 187 Baptiste Massenot, Yuri Pettinicchi

No. 186 Nicole Branger, Paulo Rodrigues, Christian Schlag

No. 185 Patrick Grüning

No. 184 Tobias Tröger

No.183 Joost Driessen, Theo E. Nijman, Zorka Simon

No. 182 Mario Bellia, Loriana Pelizzon, Marti G. Subrahmanyam, Jun Uno, Darya Yuferova

No. 181 Holger Kraft, Farina Weiss

No. 180 Tobias H. Tröger

No. 179 Tobias H. Tröger

No. 178 Matthias Goldmann

No. 177 Michael Donadelli, Marcus Jüppner, Max Riedel, Christian Schlag
Global Temperature, R\&D Expenditure, and Growth

Can Firms see into the Future?

Survey evidence from Germany

Level and Slope of Volatility Smiles in LongRun Risk Models

Heterogeneity in the Internationalization of R\&D: Implications for Anomalies in Finance and Macroeconomics

Remarks on the German Regulation of Crowdfunding

The Missing Piece of the Puzzle: Liquidity Premiums in Inflation-Indexed Markets

Coming Early to the Party

Consumption-Portfolio Choice with Preferences for Cash

Why MREL Won't Help Much

Too Complex to Work: A Critical Assessment of the Bail-in Tool under the European Bank Recovery and Resolution Regime

United in Diversity? The Relationship between Monetary Policy and Banking Supervision in the Banking Union

Temperature Shocks and Welfare Costs 